NBER WORKING PAPER SERIES

\title{
A COMPARATIVE ANALYSIS OF THE LABOR MARKET IMPACT OF INTERNATIONAL MIGRATION: CANADA, MEXICO, AND THE UNITED STATES
}

\author{
Abdurrahman Aydemir \\ George J. Borjas \\ Working Paper 12327 \\ http://www.nber.org/papers/w12327
NATIONAL BUREAU OF ECONOMIC RESEARCH
1050 Massachusetts Avenue
Cambridge, MA 02138
June 2006

We are grateful to Richard Freeman, Daniel Hamermesh, Lawrence Katz, Stephen Trejo, and three anonymous referees for helpful comments and suggestions on a previous draft. This paper represents the views of the authors and does not necessarily reflect the opinion of any institution with which the authors are affiliated. The views expressed herein are those of the author(s) and do not necessarily reflect the views of the National Bureau of Economic Research.

(C2006 by Abdurraham Aydemir and George J. Borjas. All rights reserved. Short sections of text, not to exceed two paragraphs, may be quoted without explicit permission provided that full credit, including () notice, is given to the source. 
A Comparative Analysis of the Labor Market Impact of International Migration: Canada, Mexico, and the United States

Abdurrahman Aydemir and George J. Borjas

NBER Working Paper No. 12327

June 2006

JEL No. J31, J61

\author{
Abdurrahman Aydemir \\ Family and Labour Studies Division \\ $24^{\text {th }}$ Floor, Coats Building \\ Tunney's Pasture \\ Statistics Canada \\ Ottawa, Ontario K1A 0T6 \\ CANADA \\ abdurrahman.aydemir@statcan.ca \\ George J. Borjas \\ Kennedy School of Government \\ Harvard University \\ 79 JFK Street \\ Cambridge, MA 02138 \\ gborjas@harvard.edu
}

$\underline{\text { ABSTRACT }}$

Using data drawn from the Canadian, Mexican, and U.S. Censuses, we find a numerically comparable and statistically significant inverse relation between immigrant-induced shifts in labor supply and wages in each of the three countries: A 10 percent labor supply shift is associated with a 3 to 4 percent opposite-signed change in wages. Despite the similarity in the wage response, the impact of migration on the wage structure differs significantly across countries. International migration narrowed wage inequality in Canada; increased it in the United States; and reduced the relative wage of workers at the bottom of the skill distribution in Mexico. 


\section{A COMPARATIVE ANALYSIS OF THE LABOR MARKET IMPACT OF INTERNATIONAL MIGRATION: CANADA, MEXICO, AND THE UNITED STATES}

\section{Abdurrahman Aydemir and George J. Borjas*}

\section{Introduction}

There has been a resurgence of large-scale international migration throughout much of the world in recent decades. Nearly 3 percent of the world's population now lives in a country where they were not born (United Nations, 2002). These population flows rekindled the debate over the social and economic consequences of international migration, and motivated many economists to develop and estimate models designed to measure this impact.

The North American experience with international migration—particularly in Canada, the United States, and Mexico_-stands in unique contrast to that of the rest of the world. First, Canada has long imported workers to augment its workforce. As a result, the foreign-born share in the Canadian population is higher than in most developed countries. Second, the United States receives the largest immigrant influx (in absolute size) of any country in the world. Finally, the emigration of Mexicans, almost exclusively to the United States, has drained the Mexican economy of a large fraction of its workforce in a relatively short time.

The textbook model of a competitive labor market has clear and unambiguous implications about how wages and employment opportunities in a particular country should adjust to these labor supply shifts, at least in the short run. In particular, immigration should lower the wage of competing workers.

\footnotetext{
* We are grateful to Richard Freeman, Daniel Hamermesh, Lawrence Katz, Stephen Trejo, and three anonymous referees for helpful comments and suggestions on a previous draft. This paper represents the views of the authors and does not necessarily reflect the opinion of any institution with which the authors are affiliated.
} 
Despite the common-sense intuition behind this theoretical prediction, the economics literature has — at least until recently—-found it difficult to document the inverse relation between immigrant-induced supply shifts and wages. Because immigrants typically cluster in a small number of cities in most receiving countries, much of the literature estimates the labor market impact of immigration by comparing conditions across localities in the country. These studies typically calculate the correlation between measures of immigrant penetration in local labor markets and measures of economic outcomes, such as wages (see Altonji and Card, 1991, Borjas, 1987, Card, 1991, 2001, and Grossman, 1982, for the United States; and Roy, 1997, for Canada). The sign of this "spatial correlation" is interpreted as indicating the direction in which immigrant supply shifts affect wages; a negative correlation would suggest that immigrant-induced increases in labor supply lower wages. Although there is a lot of dispersion across studies, there is a tendency towards finding a near-zero spatial correlation. This weak correlation leads to the inference that immigration has little impact on wages in the receiving country.

Borjas, Freeman, and Katz (1997) challenged this interpretation by arguing that the spatial correlation may not capture the economic impact of immigration if native workers respond by moving their labor or capital to localities seemingly less affected by the immigrant supply shock. Borjas (2003) used the insight that the labor market impact of immigration may be measurable only at the national level to examine how the wages of U.S. workers in particular skill groups - defined in terms of educational attainment and years of work experience-were related to the immigrant supply shocks affecting those groups. The national labor market evidence indicated that wage growth was strongly and inversely related to immigrant-induced supply increases. This evidence, based on the study of wage trends in the United States over four decades, is consistent with the implications of the textbook model of a competitive market. 
This paper examines if the Borjas (2003) methodological framework provides a useful approach for investigating the labor market impact of immigration outside the U.S. context. ${ }^{1} \mathrm{We}$ use the same methodology and sample design to analyze the impact of international migration in Canada, Mexico, and the United States. The joint application of the framework to these three countries is interesting for a number of reasons. First, although both Canada and the United States admit large numbers of immigrants, their different immigration policies generate immigrant populations that differ greatly in their skill mix. In Canada, immigration has disproportionately increased the number of high-skill workers. In the United States, immigration has disproportionately increased the number of low-skill workers. As a result, different groups of native workers are likely to be affected by the immigrant supply shifts in the two countries.

Second, the study of the Mexican experience should provide a mirror-image of the economic impact of migration flows. Between 1980 and 2000, immigration increased the number of working men by 13.2 percent in Canada and 11.1 percent in the United States. In contrast, Mexico experienced a 14.6 percent reduction in the size of its potential male workforce. Mishra (2005) and Hanson (2006) examine the impact of emigration on Mexican wages and find a significant positive correlation between Mexican wages and emigration. ${ }^{2}$ Our analysis confirms the existence of this basic correlation and extends the existing work. We show that the Mexican data - like the corresponding data for Canada and the United States—can be fruitfully analyzed

\footnotetext{
${ }^{1}$ We learned of two related studies after completing the initial draft of this paper. Bonin (2005) finds that supply shifts in Germany lower wages in the national German labor market, but by less than in the Borjas study. The last section of Bohn and Sanders (2005) applies the Borjas framework to the Canadian context. Using the smaller Public Use Microdata Files, they find weaker effects than those reported here (which are based on the entire Census files maintained by Statistics Canada). Aydemir and Borjas (2005) show that sampling error in measures of the immigrant supply shock calculated in small samples leads to substantial attenuation bias in estimates of the wage impact of immigration.

${ }^{2}$ Mishra's (2005) study is closely related to the descriptive analysis presented in Section 5 because that study is itself an application of the Borjas framework to the Mexican context. Hanson (2005) concludes that the Mexican wage structure shifted most favorably in those Mexican states with the largest emigration rates.
} 
using a structural model of factor demand that leads to roughly similar estimates of the elasticities of substitution. Despite this similarity, the link between the Mexican wage structure and emigration is not what one expects-namely, an increase in the relative wage of the low-skill workforce that forms the bulk of Mexican migration to the United States. Because Mexican emigration rates are relatively lower for workers at the bottom of the skill distribution, international migration may have actually reduced the relative wage of low-skill workers.

Finally, because our study analyzes similar data across the three countries (drawn from microdata samples of each country's national census) and imposes the same theoretical structure on these data, the paper reports the results of a relatively rare methodological experiment. In short, we attempt to determine if the insights implied by the laws of supply and demand lead to roughly similar qualitative and quantitative responses in the labor markets, despite the different nature of the supply shocks, institutions, and economic conditions in the three countries.

We find that there is a numerically sizable and statistically significant inverse relation between labor supply shifts and wages in all three countries. Even though the average wage response of international migration in each of the countries is relatively similar-a 10 percent labor supply shift is associated with a 3 to 4 percent opposite-signed change in wagesinternational migration plays a drastically different role in the evolution of each country's wage structure. In Canada, international migration narrowed wage inequality. In the United States, international migration increased wage inequality. In Mexico, international migration increased the relative wages of workers in the middle of the skill distribution, but lowered the relative wages of workers at the bottom of the distribution. Paradoxically, despite the large-scale migration of low-skill workers from Mexico to the United States, the wage of low-skill workers remaining in Mexico may have fallen slightly. 


\section{International Differences in Immigration Policies}

The impetus for the resurgence of large-scale immigration to the United States came from the 1965 Amendments to the Immigration and Nationality Act. Before 1965, immigration was guided by the national-origins quota system. This scheme restricted the number of immigrants, allocated visas across countries based on the national origin mix of the U.S. population in 1920, and partly used skills to allocate visas among applicants from a given country. Along with subsequent minor legislation, the 1965 Amendments repealed the national-origins quota system, set a higher numerical limit for immigration and enshrined a new objective, the reunification of families, for allocating entry visas among the many applicants.

There has also been a substantial increase in illegal immigration. It is estimated that 10.3 million illegal aliens resided in the United States in March 2005, with 5.9 million being of Mexican origin (Passel, 2005). Further, the size of the illegal population has been growing very rapidly in recent years, by around 700 thousand illegal immigrants annually since 2000 .

The increasing importance of family preferences in the awarding of entry visas, combined with the increasing number of low-skill illegal immigrants, resulted in a substantial shift in the skill composition of the foreign-born workforce: Low-skill workers became a disproportionately larger share of that workforce.

As in the United States, Canadian immigration policy until the early 1960s was based on a national-origin preference system that limited the entry of some national origin groups while facilitating the entry of others. Canada moved away from this scheme in 1962 and replaced it with a system that emphasized the skills of visa applicants. In 1967 Canada introduced the point system that aimed explicitly at selecting immigrants with desirable skills. The point system 
awards points to visa applicants who have particular socioeconomic characteristics (e.g., more schooling and fluent English or French language skills), and then sets a "passing grade" that determines the subset of visa applicants who qualify for a visa.

For the most part, immigrants who entered Canada after 1970 were admitted under one of four categories: 1) family class migrants, covering immediate family members; 2) nominated relatives, covering close relatives; 3 ) independent migrants, covering various subcategories of skilled workers as well as entrepreneurs and investors; and (4) refugees. Individuals applying under the categories of nominated relatives or independent migrants are subject to the points test.

Another important difference between the United States and Canada is the latter's explicit tie of the level of immigration to the macroeconomic environment, increasing the level during economic booms and reducing it during recessions. These adjustments often were accomplished by lowering the number of immigrants admitted under the independent migrants class. However, the tap-on, tap-off policy was abandoned in the early 1990s, and there have been relatively high immigration levels since. Because of these adjustments, the share of immigrants belonging to each of the categories has fluctuated significantly over time. The share of independent migrants rose from 21 percent in 1984 to 59 percent in 2000 (Citizenship and Immigration Canada, 2001), and over three quarters of those admitted in this category were skilled workers.

Mexico is a major source country for international migrants. The 2000 Mexican Census asked families to name the location of any relatives who had migrated abroad between 1995 and 2000, and 97 percent of these families reported the United States as the relatives' destination (Caponi, 2004). The 2000 U.S. Census enumerated 9.2 million Mexican-born persons (or 29.5 percent of all foreign-born persons in the United States). In 2000, the Mexican population stood at 100.3 million, suggesting an emigration rate of 8.4 percent. 
There are no restrictions preventing Mexicans from leaving Mexico - except for those imposed by U.S. immigration policy and border patrol enforcement. Mexican immigrants constituted the largest component of legal immigration to the United States in recent decades. In the 1990s, the United States admitted 9.1 million legal immigrants, with 24.8 percent originating in Mexico (U.S. Department of Homeland Security, 2004). As noted above, Mexicans also make up a disproportionately large share of the illegal immigrant population in the United States.

Recent studies by Chiquiar and Hanson (2005) and Ibarraran and Lubotsky (2006) examine how the skill composition of Mexican immigrants in the United States compares to that of Mexicans who remained in Mexico. The vast majority of Mexican emigrants are high school dropouts (63 percent of Mexican working men enumerated in the 2000 U.S. Census have less than 12 years of schooling). Chiquiar and Hanson (2005) point out, however, that the emigration rate is higher for Mexicans who are high school graduates than for high school dropouts.

The changes in immigration policies in Canada and the United States - and the increasingly powerful pull of the U.S. labor market to large segments of the Mexican workforce-have important implications for the trends in international migration in the three countries. Using data described in the next section, Figure 1 shows the trend in the immigrant or emigrant share in the male workforce (i.e., the fraction of the workforce aged 18-64 that is foreign-born in Canada or the United States, or the fraction of the workforce that emigrated from Mexico). The immigrant share in Canada was relatively stable over the past 30 years, hovering at around 20 percent (except for a slight dip in the 1980s). The immigrant share in the United States declined from 1960 to 1970, but increased significantly since. In 1970, less than 5 percent of the male workforce was foreign-born; by 2000, the immigrant share was almost 15 percent. Finally, 
the emigrant share in Mexico has increased dramatically. In 1970, the emigration rate of male workers was under 3 percent. By 2000, the emigration rate had risen to 16 percent.

\section{Methodological Framework and Data}

The potential problems associated with the spatial correlation approach are now well understood. Natives (and pre-existing immigrants) may respond to the adverse wage impact of immigration on local labor markets by moving their labor or capital to other cities (Borjas, 2006; Card, 2001; Filer, 1992; and Frey, 1995). These regional flows diffuse the impact of immigration across all regions, suggesting that the impact of immigration cannot be measured by comparing economic conditions across localities and may only be measurable at a national level. ${ }^{3}$

Borjas (2003) proposed a new methodology that identifies the labor market impact of immigration at the national level. We use this framework to estimate and compare the impact of international migration in three national labor markets: Canada, Mexico, and the United States. We define the skill groups that make up a national labor market in terms of education and labor market experience. This definition, of course, implicitly assumes that workers with the same level of schooling but with different levels of experience are imperfect substitutes in production (Card and Lemieux, 2001; Welch, 1979). We then use the time-variation in the share of immigrants within each skill group to identify the impact of immigration on the wage structure.

The data used in the study comes from microdata Census files for Canada, the United States, and Mexico. Our study of the Canadian labor market uses all available microdata files from the Canadian Census (1971, 1981, 1986, 1991, 1996, and 2001). Each of these files

\footnotetext{
${ }^{3}$ In addition, immigrants may not be randomly distributed across localities. If immigrants cluster in highwage cities, there would be a spurious positive correlation between immigration and wages. Employers also respond
} 
represents a 20 percent sample of the Canadian population (except for the 1971 file, which represents a 33.3 percent sample). In the U.S. context, we use the 1960, 1970, 1980, 1990 and 2000 Integrated Public Use Microdata Sample (IPUMS) of the decennial Census. The 1960 file represents a 1 percent sample of the U.S. population, the 1970 file represents a 3 percent sample, and the 1980 through 2000 files represent a 5 percent sample. Finally, our study of the Mexican labor market uses the 1960,1970, 1990 and 2000 IPUMS of the Mexican censuses (the primary documents for the 1980 census were destroyed by an earthquake). The 1960 file represents a 1.5 percent sample of the Mexican population; the 1970 file represents a 1 percent sample; the 1990 file represents a 10 percent sample; and the 2000 file represents a 10.6 percent sample. Unless otherwise indicated, the empirical analysis is restricted to men aged 18 to 64 who participate in the civilian labor force. The appendix describes the construction of the sample extracts in detail.

Our study of the U.S. data uses the convention of defining an immigrant as someone who is either a noncitizen or a naturalized U.S. citizen. In the Canadian context, we define an immigrant as someone who reports being a "landed immigrant" (i.e., a person who has been granted the right to live in Canada permanently by immigration authorities), and is either a noncitizen or a naturalized Canadian citizen. ${ }^{4}$ Finally, although the Mexican census does not provide a count of the number of emigrants, almost all Mexican emigrants chose the United States as their destination. Hence a count of the number of Mexican emigrants can be obtained from the U.S. Census (abstracting from the undercount problem in that Census). More precisely,

by changing the factor mix (Lewis, 2005). The shift in the factor mix, however, would presumably be induced by the changing relative price of labor, so that the wage impact of immigration should be observed at least in the short run.

${ }^{4}$ The Canadian Censuses include non-permanent residents since 1991. This group includes those residing in Canada on an employment authorization, a student authorization, a Minister's permit, or who were refugee claimants at the time of Census (and family members living with them). Non-permanent residents account for less than 1 percent of the samples used in this study since 1991, and are included in the immigrant counts for those years. 
the number of emigrants from Mexico at a particular point in time is given by the number of Mexican-born persons enumerated by the corresponding U.S. Census.

We define skill groups in terms of educational attainment and years of labor market experience. To analyze the Canadian trends, we classify workers into five distinct education groups using the detailed information on the type of degree available in the Canadian census.

The five education groups are: (1) workers who are high school dropouts; (2) workers who have either a high school or a vocational degree; (3) workers who have a high school and vocational degree or have a post-secondary certificate or diploma below the bachelor's degree; (4) workers who have a bachelor's degree; and (5) workers who have a post-graduate degree.

Our analysis of the U.S. data uses five education groups that roughly correspond to the Canadian categories: (1) high school dropouts (workers who have less than 12 years of completed schooling); (2) high school graduates (workers who have exactly twelve years of schooling); (3) workers who have some college (thirteen to fifteen years of schooling); (4) college graduates (workers who have exactly sixteen years of schooling); and (5) workers with post-graduate education (workers who have more than 16 years of schooling). ${ }^{5}$

The Mexican schooling system differs greatly from that of Canada or the United States. Students get a primary-level degree after 6 years of education, a lower-secondary degree after 9 years, and a secondary level degree after 12 years. There are, therefore, spikes in the educational distribution at these termination points. The bulk of Mexican working men are "high school dropouts" - in the sense that they did not have a secondary level degree — in the period under

\footnotetext{
5 In Canada, "college" typically refers to 2-year post-secondary institutions that grant a certificate or diploma below Bachelor's level. Throughout the text, however, we use the term "college graduate" to refer to Bachelor's degree holders in all three countries that we study.
} 
study (94.9 percent in 1970 and 73.4 percent in 2000). ${ }^{6}$ We use five education groups in Mexico to capture key features of the Mexican system: (1) high school dropouts with 0 to 8 years of schooling (i.e., workers who have less than a lower secondary education); (2) high school dropouts with 9 to 11 years of schooling (i.e., workers who have completed a lower secondary education); (3) high school graduates (i.e., workers who have completed a secondary education, either in a general or technical track); (4) workers with some college (i.e., workers who report completing a general track secondary education and also attending some college, or workers who completed a technical track secondary education and obtained a post-secondary technical degree); and (5) college graduates (i.e., workers who completed a university education). ${ }^{7}$ Finally, because we rely on the U.S. Census to enumerate Mexican emigrants, we define five corresponding education groups in the U.S. data, based on their years of completed schooling. ${ }^{8}$

We group workers into a years-of-experience cohort by using potential experience, roughly defined by Age - Years of Education - 6. The Canadian Census reports the number of years that a worker attended grade school, post-secondary education below university, and university. By adding these variables, we can calculate the total years of schooling. The U.S. and Mexican Censuses do not report the number of years of school attended in such detail. We assume that age of entry into these labor markets is 17 for high school dropouts, 19 for high school graduates, 21 for persons with some college, 23 for college graduates, and 25 for persons

\footnotetext{
${ }^{6}$ The mandatory level of schooling in Mexico was 6 years until 1992 and 9 years hence. Therefore, Mexican workers with less than 12 years of schooling are not "dropouts" in the sense meant in Canada or the United States. For convenience, we use "high school dropouts" to denote workers who have not completed high school.

${ }^{7}$ In 2000, 45.0 percent of male workers in Mexico were high school dropouts with 0 to 8 years of schooling, 28.4 percent were high school dropouts with 9-11 years, 11.2 percent were high school graduates, 3.9 percent had some college, and 11.6 percent were college graduates.

${ }^{8}$ The education groups used to classify Mexican emigrants are: 0-8 years of schooling, 9-11 years, 12 years, 13-15 years, and at least 16 years.
} 
with post-graduate degrees. ${ }^{9}$ The analysis is restricted to persons who have between 1 and 40

years of experience. Workers are aggregated into five-year experience intervals (i.e., 1 to 5 years

of experience, 5 to 10 years, and so on) to capture the notion that workers who have roughly

similar experience are more likely to affect each other's labor market opportunities than workers

who do not.

The skill cells corresponding to educational attainment $(s)$, experience $(x)$, and calendar year $(t)$ define a skill group at a point in time for a given national labor market (for convenience, we omit the index indicating the country). ${ }^{10}$ Define the immigrant supply shock by:

$$
p_{s x t}=\frac{M_{s x t}}{\left(M_{s x t}+N_{s x t}\right)},
$$

where, in the case of Canada and the United States, $M_{s x t}$ gives the total number of immigrants in the particular skill group; and $N_{s x t}$ gives the total number of native workers in that group. The variable $p_{s x t}$ then gives the immigrant share (i.e., the fraction of the relevant workforce that is foreign-born). In the Mexican context, $M_{s x t}$ gives the number of emigrants belonging to a particular skill group (as enumerated by the U.S. Census); and $N_{s x t}$ represents the number who

${ }^{9}$ This approximation is probably much more appropriate for workers in the United States than in Mexico, particularly for the least educated workers. We experimented with alternative assumptions (e.g., high school dropouts enter the labor market at age 15) and the results are similar to those reported below.

10 The classification of immigrants and natives with the same schooling and experience into the same skill groups may generate misclassification biases. It is well known that employers in receiving countries typically attach different values to schooling or experience acquired before and after immigration. Borjas (2003) reports a number of sensitivity tests (such as rescaling the value of experience obtained abroad to calculate the "effective" experience of a foreign-born worker) and concludes that the U.S. estimates are not very sensitive to alternative classifications. We conducted a similar sensitivity analysis for Canada and found similar results. In Section 6 below, we specifically examine the hypothesis that immigrants and natives are perfect substitutes in Canada and the United States and find that we cannot reject the null hypothesis of perfect substitution in either country. 
remained in Mexico. The variable $p_{s x t}$ then gives the emigrant share (i.e., the fraction of workers in a particular skill group who have left the country).

\section{Trends in International Migration by Skill}

We first show the trends in immigration and emigration across education groups for each of the three countries. Figure 2 illustrates the education-specific trends in the immigrant/emigrant shares. In Canada, the immigrant share among workers with at most a high school degree was either constant or declined slightly, while the immigrant share among workers with some college declined substantially. At the same time, the immigrant share among workers who have at least a college degree increased rapidly. The immigrant share among college graduates rose from 21.4 to 26.7 percent between 1986 and 2001, and the immigrant share among workers with a postgraduate degree rose from 32.5 to 38.2 percent. This shift towards a high-skill immigrant influx was precisely the goal of the point system.

The U.S. experience stands in striking contrast. Although the immigrant share among highly educated workers (particularly among workers with a post-graduate education) increased, the increase was much more rapid among workers who are high school dropouts. As recently as 1980, only 10.9 percent of the high school dropout workforce was foreign-born. By 2000, 40.9 percent were foreign-born. In contrast, the immigrant share among college graduates was 7.3 percent in 1980 and rose to 13.4 percent in 2000, while the immigrant share among post-graduate degree holders was 9.0 percent in 1980 and rose to 17.1 percent in 2000.

The bottom panel of the figure shows that the emigration rate for Mexicans is larger for workers in the middle of the education distribution (i.e., for workers who are either high school graduates or have some college). Mexico, however, has relatively few workers with this 
"middle" level of education. As a result, even though the emigration rate for high school dropouts is relatively low, there is a sizable numerical outflow of low-skill workers. Moreover, the emigration rate of Mexican high school dropouts, particularly of the least-educated high school dropouts, has risen rapidly, from 8.6 to 16.0 percent between 1990 and 2000. Finally, Mexicans with a college degree have the lowest emigration rate (5.3 percent in 2000).

The merging of Mexican and U.S. Census data to calculate emigration rates raises two problems. First, the potential undercount of Mexican immigrants in the U.S. Census suggests that Mexican emigration rates are underestimated, particularly for low-skill workers. We discuss how the undercount biases the estimated wage impact of immigration below.

Second, we assumed that the education of Mexicans now residing in the United States is the educational attainment that would have been observed had these workers remained in Mexico. This assumption does not create a problem for Mexicans who migrated as adults because only a very small number of these adults get additional schooling in the United States (6.9 percent of Mexicans who migrated between the ages of 15-24 during the 1990s were enrolled in school in 2000). However, the assumption may be less plausible for Mexicans who migrated as children and we may be assigning too much education to these workers. It turns out, however, that only 20.6 percent of the Mexicans in our 2000 U.S. Census sample migrated before age $14 .{ }^{11}$ We will show below that our results are not sensitive to alternative assumptions about the educational attainment of this subsample of workers.

11 Although the potential misplacement of the "child immigrants" into more skilled groups could potentially explain the large emigration rates of Mexican workers in the middle of the skill distribution, the "adjusted" rates are still lower for high school dropouts. Suppose we assign all child immigrants from Mexico the educational distribution of comparably aged Mexicans who did not emigrate. In 2000, this counterfactual increases the emigration rate of high school dropouts with $0-8$ years of schooling from 16.0 to 17.6 percent, and decreases the emigration rate of high school graduates from 29.7 to 25.7 percent. 
There also exist differences in the age structure of international migrants in the three countries, and the nature of these differences changes over time. Figures 3 and 4 illustrate the trends for Canada and the United States, respectively. ${ }^{12}$ In general, the recent immigrant influx to the United States tends to most increase the supply of younger workers, while the influx in Canada tends to most increase the supply of older workers. In 2001, the immigrant share among the youngest college-educated Canadians was around 20 percent. In contrast, over 30 percent of Canadian workers who are college graduates and have at least 30 years of experience were foreign-born. In the United States, the immigrant share among younger college graduates hovered around 12 percent, while the immigrant share among their older counterparts was 7 percent. The Canadian workers who are most likely to be adversely affected by immigration seem to be a mirror image of the American workers who are most vulnerable to immigrantinduced supply shifts. In the United States, the targeted natives seem to be younger, low-skill workers. In Canada, they seem to be older, high-skill workers.

Figure 5 shows the trends in Mexican emigration rates. There has been a significant change in the age distribution of low-skill emigrants. Before 1990, emigration rates for low-skill workers were either relatively constant across experience categories or tended to be higher for older workers. By 2000, the emigration rates of high school dropouts exhibit an inverse-U shape: emigration rates tend to be largest for high school dropouts with 15 to 25 years of experience.

The supply shifts illustrated in Figures 3-5 form the key independent variable in our analysis. We wish to determine the link between these supply shifts and the evolution of wages in each country. The earnings data are drawn from the respective Censuses. We restrict our calculation of mean log earnings for each skill group (i.e., each $s, x, t$ cell in each country) to

\footnotetext{
12 To avoid clutter, we only show the trend lines for selected Census years.
} 
workers who, in addition to the restrictions listed earlier, are not enrolled in school and report valid earnings information. Our sample extract includes both salaried and self-employed workers. In the case of the Canadian and U.S. censuses, the earnings data refer to annual earnings in the year prior to the Census. We use these data to construct measures of mean log annual earnings and mean log weekly earnings for each cell. The Mexican census reports the worker's monthly earnings. All earnings are deflated to constant dollars (1999 for the United States and 2000 for Canada and Mexico).

Figure 6 plots the time series of the wage gap between college graduates and high school dropouts for both young (6 to 10 years of experience) and older (31 to 35 years of experience) workers, as well as the wage gap between college graduates and high school graduates. ${ }^{13}$ The relative wage of young high-educated workers rose in both Canada and the United States after 1980, but the trends differ for older workers: the relative wage of older college graduates rose in the United States, but fell in Canada. It is curious that the workforce of older, high-skill workers is the one that was hit hardest by immigrant-induced supply shifts in Canada. Although the different evolution of the wage structure in the two countries has received a great deal of attention, the factors generating these differences are still not well understood (Beaudry and Green, 2000; Boudarbat, Lemieux, and Riddell, 2003; and Card and Lemieux, 2001).

The trends in the relative wage of high skill workers in Mexico bear little resemblance to either the Canadian or U.S. trends. The relative wage of Mexican high-skill men fell substantially before 1990, before rising slowly in the 1990s. The remainder of this paper attempts to determine if the cross-country differences in the evolution of relative wages can be partly understood in terms of the immigration-induced supply shifts experienced by each country. 


\section{Descriptive Results}

Let $y_{s x t}$ denote the mean value of a particular labor market outcome for men who have education $s$, experience $x$, and are observed at time $t$. We calculate $y_{\text {sxt }}$ using the sample of native-born men in our study of the Canadian and U.S labor markets, and the sample of Mexicans residing in Mexico (i.e., the "stayers") in our study of the Mexican labor market. The empirical analysis reported in this section stacks these data across skill groups and calendar years and estimates the following regression model separately by country:

$$
y_{s x t}=\theta p_{s x t}+S+X+T+(S \times X)+(S \times T)+(X \times T)+\xi_{s x t}
$$

where $S$ is a vector of fixed effects indicating the group's educational attainment; $X$ is a vector of fixed effects indicating the group's work experience; and $T$ is a vector of fixed effects indicating the time period. The linear fixed effects in equation (2) control for differences in labor market outcomes across schooling groups, experience groups, and over time. The interactions $(S \times T)$ and $(X \times T)$ allow for the impact of education and experience to change over time, and the inclusion of the interaction $(S \times X)$ implies that the labor market impact of labor supply shocks is identified using time-variation within education-experience cells. All regressions are weighted by the number of observations used to calculate the dependent variable $y_{s x t}{ }^{14}$ The standard errors are clustered by education-experience cells to adjust for possible serial correlation.

\footnotetext{
13 To simplify the presentation, Figure 6 pools together all persons with at least a college diploma in Canada and the United States and pools together all high school dropouts in Mexico.

14 We normalized the sum of weights to equal 1 in each cross-section in the Canadian and U.S. regressions to prevent the later censuses from contributing more to the results simply because population increased over time. In
} 
The dependent variables used in our study of labor market outcomes in Canada and the United States include the mean of log earned annual income and log earned weekly income, as well as the fraction of weeks worked (defined as weeks worked in the calendar year prior to the Census divided by 52 in a sample of all persons, including nonworkers). The Mexican census provides limited information on labor market outcomes. We use the log of earned monthly income. ${ }^{15}$ Because of differences in the coding of work status across survey years in the Mexican census, we use the labor force participation rate of the skill group as a dependent variable. ${ }^{16}$

Table 1 reports the estimates of the adjustment coefficient $\theta$. Row 1 presents the results for Canada. Consider initially the case when the dependent variable is the log weekly earnings of native Canadian workers. The coefficient is -0.507 , with a standard error of 0.202 . It is easier to interpret this coefficient by converting it to an elasticity that gives the percent change in wages associated with a percent change in labor supply. Let $m_{s x t}=M_{s x t} / N_{s x t}$, or the immigrant-induced percentage increase in the labor supply of group $(s, x, t)$. We define the "wage elasticity" as:

$$
\frac{\partial \log w_{s x t}}{\partial m_{s x t}}=\frac{\theta}{\left(1+m_{s x t}\right)^{2}} .
$$

\footnotetext{
Mexico, however, the pre-1990 Census represents roughly a 1 percent random sample, while the 1990 and 2000 Census represent a 10.0 percent random sample (the 1970 Mexican census has 483,000 observations and the 2000 census has 10.1 million observations). Because the pre-1990 cell means may be measured with error, we use the actual sample size as the weight in all Mexican regressions. We also estimated unweighted specifications of the regression models. The weighted and unweighted coefficients are similar for Canada and the United States, as well as in Mexico for the post-1990 period.

15 The monthly income variable in the 1970 Mexican census includes earned and unearned income.

16 The 1960 Mexican census does not provide detailed information on a person's work status. Hence our analysis of labor force participation rates uses only the 1970-2000 surveys.
} 
By 2000, immigration had increased the number of workers in the Canadian labor market by 25.8 percent. Equation (3) implies that the wage elasticity—evaluated at the mean value of the immigrant supply increase — can be obtained by multiplying $\theta$ by approximately 0.63 . The wage elasticity for weekly earnings is then -0.32 (or $-0.507 \times 0.63$ ). Put differently, a 10 percent immigrant-induced increase in the number of workers in a particular skill group reduces the wage of that group by 3.2 percent. ${ }^{17}$

The other coefficients reported in the first row of Table 1 indicate that immigration has a slightly more negative impact on the annual earnings of native Canadian workers, implying that immigration reduces their labor supply. In fact, the coefficient in the fraction of weeks worked regression is negative and significant. An immigrant-induced 10 percent increase in labor supply reduces annual earnings by 3.9 percent and the fraction of time worked by 1.5 percentage points.

Row 2 of Table 1 reports the corresponding estimates for the United States. The estimated coefficient in the log weekly earnings regression is -0.489 , with a standard error of 0.223. A test of equality for the adjustment coefficient in the log weekly earnings regression estimated in Canada and the United States would obviously not reject the hypothesis that the two coefficients are equal. By 2000, immigration had increased the number of male workers in the U.S. labor market by 17.2 percent. Equation (3) implies that the wage elasticity can be estimated by multiplying the coefficient $\theta$ by 0.73 . The wage elasticity in the U.S. is then equal to -0.36 , essentially the same numerical response as in Canada. The data also indicate that annual earnings are more sensitive to immigration in the United States than in Canada, mainly because the labor supply of native workers in the United States is more sensitive to immigration (although the

\footnotetext{
17 The regression model in (2) uses the immigrant share, $p$, rather than the relative number of immigrants, $m$, as the regressor because the labor market outcomes used in this paper tend to be nonlinearly related to $m$, and $p$ is approximately a linear function of $\log m$.
} 
hypothesis that the coefficients in the log annual earnings regressions are equal cannot be rejected). An immigrant-induced 10 percent increase in supply reduces the fraction of time worked by 2.5 percentage points, and reduces annual earnings by 6.2 percent.

Finally, row 3 of the table reports the results for Mexico. Our evidence confirms Mishra's (2005) finding of a positive correlation between the log monthly earnings of Mexican workers in a particular skill group and the emigration rate of that group. The coefficient is $+0.798(0.443)$. By 2000, the large-scale emigration of workers from Mexico had reduced the size of the Mexican workforce by 19.1 percent, implying that the wage elasticity is obtained by multiplying the adjustment coefficient times 0.70 . The implied wage elasticity is +0.559 , indicating that a 10 percent emigrant-induced reduction in labor supply increases monthly earnings by 5.6 percent. Given the relatively large standard errors of the adjustment coefficients, the data cannot reject the hypothesis that the three wage elasticities are equal (in absolute value).

The inter-country comparison of the estimated elasticities is not straightforward because it is difficult to interpret the Mexican monthly earnings data. First, the earnings data provided by the 1970 Mexican census (total personal income) is not directly comparable to the data provided by the other censuses (total earned income). However, the different earnings definitions across survey years do not substantially bias the adjustment coefficient. The fourth row of Table 1 reestimates the model using only data drawn from the 1990 and 2000 cross-sections, and finds that the adjustment coefficient is quite similar ( 0.841 with a standard error of 0.540$)$.

It is also unclear if the elasticity estimated in a monthly earnings regression in Mexico is more comparable to an elasticity estimated in an annual or weekly earnings regression in the other countries. Workers were asked to report their earned income, and the census questionnaire allowed several reporting options. Workers could report weekly, bimonthly, monthly, or annual 
earnings. The Mexican census bureau then used these responses to construct the publicly available "monthly earnings" variable. ${ }^{18}$ Although it is common for many Mexican workers to be paid by the month, there is also a large seasonal component in employment, particularly in the rural sector. As a result, variation in the monthly earnings measure may be capturing seasonal differences in labor supply across workers (making Mexican monthly earnings conceptually more similar to annual earnings in Canada or the United States). We re-estimated the regression model using the subsample of urban Mexican workers, a subset of workers unlikely to be affected by seasonal fluctuations in agricultural demand. Row 5 of Table 1 clearly shows a drop in the estimate of the Mexican adjustment coefficient to +0.652 (0.419). The wage elasticity implied by the regression in the urban workers sample is +0.46 .

Table 1 also documents that the labor supply of Mexicans who remained behind is positively affected by the emigration of their compatriots. We estimated equation (2) using the labor force participation rate of the skill group as the dependent variable. The adjustment coefficient is positive (though not significant).

Two technical issues are worth emphasizing. First, we assumed that immigrant-induced supply shifts are exogenous. Income-maximizing behavior on the part of migrants suggests that the immigration rate is higher when wages at the destination are relatively high, and that the emigration rate is higher when wages at the source are relatively low. The endogeneity implies that the negative wage effect of immigration estimated in receiving countries is a lower bound for the true negative impact, and that the positive wage effect estimated in sending countries is a

\footnotetext{
18 The description of how monthly earnings were constructed does not seem to be publicly available.
} 
lower bound for the true positive impact. In short, endogenous migration flows lead to an understatement (in absolute value) of the true wage impact of migration. ${ }^{19}$

Second, the undercount problem in the U.S. Census implies that the Mexican emigration rates are measured with error. The noise in the variable would attenuate the measured wage impact of immigration. The undercount, however, may be larger in cells representing workers with the lowest (unobserved) skills. This correlation would tend to make the adjustment coefficient more positive. It is impossible, therefore, to sign the direction of the bias.

We conducted a variety of sensitivity tests to determine the robustness of our findings to major specification changes. Table 2 reports the regression coefficient $\theta$ obtained from these additional specifications using the log of annual earnings and the log of weekly earnings for Canada and the United States, and the log of monthly earnings for Mexico. For reference purposes, the first row of the table duplicates the baseline coefficients estimated in Table 1.

As noted earlier, we restrict our study to the sample of working men. The second row of Table 2 reports the estimated coefficient $\theta$ when the measure of the immigrant or emigrant share $p_{s x t}$ uses information on both male and female workers. Despite the likely misclassification of many women into the various experience categories, the estimated coefficients have roughly the same numerical values as those reported in the baseline row. Similarly, row 3 shows that our findings are unaffected even when we calculate the mean log earnings for the cell using the sample of working men and women.

Row 4 returns to the baseline sample of male workers but reports the labor market impact of immigration on salaried workers. The exclusion of the self-employed from the analysis in

\footnotetext{
${ }^{19}$ A negative correlation between the wage of low-skill natives in the United States and immigration could also arise if more recent cohorts of high school dropouts have lower unobserved productivity than earlier cohorts.
} 
Canada and the United States leads to roughly similar adjustment coefficients as those reported in the baseline row. The adjustment coefficient for Mexico, however, falls by about half, and is less significant. Nevertheless, the use of the salaried sample leads to a remarkable aligning of the adjustment coefficient across all three countries. The drop in the Mexican coefficient probably occurs because, as noted earlier, the log of monthly earnings in the Mexican census may contain an important labor supply component, and this labor supply variation may be substantially greater among the self-employed.

Our empirical analysis has used a 5-year experience band to aggregate workers into the various skill groups. As row 5 of Table 2 shows, the estimated coefficients are unaffected when we exclude workers who have just entered the labor market (i.e., have fewer than 5 years of experience) or workers who are about to retire (have more than 35 years of experience).

Similarly, row 6 indicates that the results are robust when we use a 10-year experience band (i.e., 1-10 years of experience, 11-20 years, and so on) to define the skill groups.

The remaining rows of Table 2 show the sensitivity of the results to alternative definitions of the schooling categories or to the wholesale exclusion of particular schooling groups. For instance, we have used a five-way educational classification in all three countries. Row 7 of the table illustrates what happens when we estimate the regressions using only 4 education groups by pooling all college graduates in Canada and the United States, and pooling all high school dropouts in Mexico. As the table shows, a four-way classification of education groups in the three countries actually leads to slightly more negative adjustment coefficients in Canada and the United States, and a much more positive coefficient in Mexico.

The increasing negative selection of this population may have induced U.S. firms to increase their demand for lowskill immigrants. Although this is an interesting hypothesis, it has not been examined in the literature. 
It is also of interest to determine if the results are driven by a particular education group. Row 8 illustrates the impact of removing the sample of high school dropouts from the analysis in the United States and Canada. The results for Canada are not greatly affected, but the results for the United States become much weaker and are no longer statistically significant. Row 9 reports an equally interesting exercise when we redefine the high school dropout category to include only workers who have between 9 and 11 years of schooling. In 2000, only 22.3 percent of native high school dropouts in the United States had fewer than 8 years of schooling, as compared to 68.0 percent of foreign-born dropouts. It is unclear that the typical low-skill immigrant competes in the same labor market as the typical native dropout. To analyze the sensitivity of our results to this potential mismatch, we excluded from the calculation of both the cell-specific labor market outcomes and supply shifts any workers who have fewer than 8 years of school. The high school dropout category, therefore, now includes only workers who have 9 to 11 years of schooling. Row 9 of Table 2 shows that the estimated adjustment coefficients in the United States are now negative, but have large standard errors.

Row 10 provides a mirror image result for Canada. If we omit all college graduates from the analysis, the U.S. results are basically unchanged, but the Canadian adjustment coefficients are near zero. If we only exclude the most highly educated workers from the data (workers with post-graduate education), row 11 shows that the adjustment coefficients again becomes negative and close in value to that presented in the baseline row. The lesson, therefore, seems to be that the negative labor market impact of immigration remains visible as long as we do not remove from the data almost all of the variation in the immigrant supply shock.

Finally, row 12 shows that the results are unchanged when we adjust the Mexican emigration rates for the possibility that "child immigrants" would have obtained far less 
education had they remained in Mexico. In particular, we assign each person who was 14 or younger at the time of their emigration the educational distribution of comparably aged Mexicans who remained in Mexico. Table 2 shows that this counterfactual measure of the Mexican emigration rates barely changes the estimated wage impact of international migration on Mexican wages.

In sum, a systematic study of wages in three countries greatly affected by immigration reveals that immigrant-induced labor supply shifts generate opposite-signed changes in the wage, as predicted by the simplest textbook model of a competitive labor market. Remarkably, these wage responses seem to be of almost the same magnitude across countries. A 10 percent shift in supply generates a 3 or 4 percent opposite-signed shift in wages.

\section{Structural Estimates}

\subsection{Theory and Evidence}

The descriptive exercise summarized in the previous section reveals an important inverse correlation between supply shifts and wages. That exercise did not impose any theoretical structure to estimate the response elasticities. A fuller understanding of the underlying correlation (and of its implications) requires imposing more structure on the data by specifying the technology of the aggregate production function and adding the profit-maximization behavioral assumption. This structural approach makes it possible to estimate not only the effect of a particular supply shift on the wage of competing workers, but also the cross-effects on the wage of other workers. ${ }^{20}$

\footnotetext{
20 The three-level CES technology presented here slightly generalizes the two-level approach used by Bowles (1970) and Card and Lemieux (2001).
} 
As in Borjas (2003), suppose that the aggregate technology for a national economy at time $t$ is given by the linear homogeneous production function:

$$
Q_{t}=\left[\left(1-\lambda_{L t}\right) K_{t}^{v}+\lambda_{L t} L_{t}^{v}\right]^{1 / v}
$$

where $Q$ is output, $K$ is capital, $L$ denotes the aggregate labor input, and $v=1-1 / \sigma_{K L}$, with $\sigma_{K L}$ being the elasticity of substitution between capital and labor $(-\infty<v \leq 1)$. The aggregate $L_{t}$ incorporates the contributions of workers who differ in both education and experience. Let:

$$
L_{t}=\left[\sum_{s} \theta_{s t} L_{s t}^{\rho}\right]^{1 / \rho}
$$

where $L_{s t}$ gives the number of workers with education $s$ at time $t$, and $\rho=1-1 / \sigma_{E}$, with $\sigma_{E}$ being the elasticity of substitution across these education aggregates $(-\infty<\rho \leq 1)$. The $\theta_{i t}$ give technology parameters that shift the relative productivity of education groups, with $\Sigma_{i} \theta_{i t}=1$. Finally, the supply of workers in each education group is itself given by an aggregation of the contribution of similarly educated workers with different experience. In particular:

$$
L_{s t}=\left[\sum_{x} \alpha_{s x t} L_{s x t}^{\eta}\right]^{1 / \eta}
$$

where $L_{s x t}$ gives the number of workers in education group $s$ and experience group $x$ at time $t$; and $\eta=1-1 / \sigma_{X}$, with $\sigma_{X}$ being the elasticity of substitution across experience classes within an 
education group $(-\infty<\eta \leq 1)$, with $\Sigma_{x} \alpha_{s x t}=1$. Note that equation (6) implicitly assumes that native and immigrant workers with the same education and experience are perfect substitutes in production. We will test the validity of this assumption below.

The elasticities of substitution $\sigma_{X}$ and $\sigma_{E}$ can be estimated from a two-equation system using the data on mean wages and immigrant supply shifts summarized in the previous sections. Profit maximization implies that the wage for skill group $(s, x, t)$ can be written as:

$$
\log w_{s x t}=\delta_{t}+\delta_{s t}+\delta_{s x t}-\frac{1}{\sigma_{X}} \log L_{s x t},
$$

where $\delta_{t}=\log \lambda_{L t}+(1-v) \log Q_{t}+(v-\rho) \log L_{t}$, and is absorbed by period fixed effects; $\delta_{s t}=$ $\log \theta_{s t}+(\rho-\eta) \log L_{s t}$, and is absorbed by interactions between the education fixed effects and the period fixed effects; and $\delta_{s x t}=\log \alpha_{s x t}$. The vector $\delta_{\text {sxt }}$ cannot be absorbed by educationexperience-period fixed effects because there would be as many fixed effects as there are observations. An identifying assumption is that $\delta_{\mathrm{sxt}}$ can be decomposed into a portion that is time-invariant plus a random term. This assumption gives a stochastic version of equation (7):

$$
\log w_{s x t}=\delta_{t}+\delta_{s t}+\delta_{s x}-\frac{1}{\sigma_{X}} \log L_{s x t}+v_{s x t},
$$

The vector $\delta_{s x}$ is now absorbed by interactions between education fixed effects and experience fixed effects. The regression model in $\left(7^{\prime}\right)$, therefore, identifies the elasticity of substitution across experience groups. 
Because the coefficients of the education-experience interactions in ( $\left.7^{\prime}\right)$ identify $\log \alpha_{s x}$, the estimates of $\alpha_{s x}$ and $\sigma_{X}$ permit the calculation of $L_{s t}$, the CES-weighted aggregate for education group $s .{ }^{21} \mathrm{We}$ can then move up one level in the CES technology, and recover the elasticity of substitution across education groups. Let $\log w_{s t}$ be the mean log wage paid to the average worker in education group $s$ at time $t$. The marginal productivity condition determining the wage for this group is:

$$
\log w_{s t}=\delta_{t}+\log \theta_{s t}-\frac{1}{\sigma_{E}} \log L_{s t}
$$

This equation is closely related to the relative demand function estimated by Katz and Murphy [1992, p. 69] that examines how the skill wage differential varies with relative supplies in the United States. Note that $\sigma_{E}$ cannot be identified if the regression included interactions of education-period fixed effects to absorb the term $\log \theta_{s t}$. There would be as many fixed effects as there are observations. We initially use the Katz-Murphy identifying assumption that the technology shifters can be approximated by a linear trend that varies across education groups and an uncorrelated residual. ${ }^{22}$ We can then rewrite equation (8) as:

$$
\log w_{s t}=\delta_{t}+\text { education-specific linear trends }-\frac{1}{\sigma_{E}} \log L_{s t}+\xi_{s t} .
$$

${ }^{21}$ If $\log \hat{\alpha}_{i j}$ is an estimated fixed effect coefficient, then $\hat{\alpha}_{i j}=\exp \left(\log \hat{\alpha}_{i j}\right) / \sum_{j} \exp \left(\log \hat{\alpha}_{i j}\right)$, which imposes the restriction that the sum of the $\alpha$ 's is 1 . This calculation ignores the random time variation in the $\alpha_{s x}$. We also estimated the second-stage models using actual employment as the independent variable, rather than the CES aggregate. The results were very similar to those reported below. 
Ordinary least squares regressions of equations $\left(7^{\prime}\right)$ and $\left(8^{\prime}\right)$ may lead to biased estimates of $\sigma_{X}$ and $\sigma_{\ddot{E}}$ because the supply of workers to the various education groups is likely to be endogenous. We assume that the immigrant or emigrant influx in a particular country provides the supply shifter that identifies the labor demand function. This instrument is valid if the flow of international migrants into or out of particular skill groups were independent of the relative wages offered to the various skill categories. However, the number of international migrants in a skill group likely responds to shifts in the wage structure. Income-maximizing behavior on the part of potential immigrants (emigrants) would generate larger (smaller) supplies in those skill cells that had relatively high (low) wages. This behavioral response builds in a positive correlation between the number of migrants and wages in a skill group. The IV coefficients, therefore, understate the negative wage impact of a relative supply increase.

Finally, the empirical implementation of the three-level CES technology described above does not use any data on the aggregate capital stock, making it difficult to separately identify the value of $\sigma_{K L}$. We will discuss below plausible assumptions that can be made about this parameter to simulate the impact of immigration on the labor market.

The first row of Table 3 reports the estimated $\sigma_{X}$ for Canada, Mexico, and the United States. ${ }^{23}$ In the United States, our estimate of $1 / \sigma_{X}$ is 0.321 (with a standard error of 0.120 ). This implies an elasticity of substitution across experience groups of around 3 . The same regression

\footnotetext{
22 The Katz-Murphy assumption is based on an analysis of U.S. wages trends and may not hold in other countries. We address this point in more detail below.

23 The coefficient of the instrument in the reduced-form regression is 0.940 (0.058) in Canada; 0.278 (0.078) in the United States; and $0.240(0.173)$ in Mexico. The $F$-statistic is above the threshold required to reject the hypothesis that the immigrant influx is a weak instrument (an $F$-statistic above 10) in Canada and the United States, but not in Mexico.
} 
estimated in Canada yields the much lower estimate for $1 / \sigma_{X}$ of $0.030(0.015)$, while the same regression estimated in Mexico implies that $1 / \sigma_{X}$ equals $0.286(0.136)$. The estimate of $\sigma_{X}$ in Canada, therefore, represents an outlier.

As noted above, the framework imposed an important restriction in the estimation of $\sigma_{X}$. In particular, equation (7) does not include any fixed effects to absorb experience-specific changes in wages over time (the $X \times T$ fixed effects). This restriction follows directly from the identifying assumption that the coefficients $\alpha_{s x}$ were time-invariant. One simple way of relaxing this assumption is to allow for linear trends, specific to each experience group, that influence the evolution of wages (see Card and Lemieux, 2001, Table 4). Row 2 of Table 3 includes these experience-specific trends. The estimated $1 / \sigma_{X}$ now falls within a narrower range for all three countries: 0.135 (0.037) for Canada; $0.122(0.038)$ for the United States; and 0.234 (0.072) for Mexico. These coefficients imply an elasticity of substitution across experience groups of between 4 and 8 . Note that the estimated coefficients are only a bit lower than those estimated by Card and Lemieux (2001, Table 4) using a very different conceptual experiment, where the estimate of $1 / \sigma_{X}$ lies between 0.17 and 0.20 in Canada and the United States.

We use the elasticities of substitution estimated in row 2 to calculate the CES-weighted aggregates of the workforce for each education group. As noted earlier, we initially assume that the pattern of demand shifts for the various education groups can be approximated by educationspecific linear trends. Row 3 of Table 3 reports the estimates obtained from this specification. The IV estimate of the coefficient of the log of the number of workers in a skill group (which estimates the parameter $\left.-1 / \sigma_{E}\right)$ is negative in the United States $(-0.273$, with a standard error of 
0.153), essentially zero in Canada, and very large and negative in Mexico (a coefficient of -2.02 , with a standard error of 1.59). ${ }^{24}$

Other studies have found that the coefficient estimating the relation between relative wages of different education groups in Canada and relative supplies is nearly zero when one assumes a linear trend (Card and Lemieux, 2001, Table 4). Beaudry and Green (2000) conclude that the Katz-Murphy linear trend assumption does not fit the Canadian data and may not provide a useful simplification for understanding how relative supplies affect the wage gap across different education groups in Canada.

In fact, Autor, Katz and Kearny (2004) have recently argued that the linear trend assumption also fails to capture what happened to the U.S. wage structure after 1992. They document a 20 percent decline in the secular growth rate of demand for skilled workers during the 1990 s as compared to the growth rate prior to the 1990 s. To capture this break in the linear trend, we included education-specific splines in equation (8) that allow for a change in the intercept and a change in the slope of the trend in the 1990s. Row 4 of Table 3 shows that the estimate of $1 / \sigma_{E}$ with this nonlinear trend is 0.327 , although it is estimated imprecisely. ${ }^{25}$ This point estimate implies that the elasticity of substitution across education groups is 3.1 , roughly twice the size of the Katz-Murphy estimate of 1.4 .

24 The coefficient of the instrument in the reduced-form regression is $0.799(0.117)$ in Canada; 0.665 (0.184) in the United States; and -0.701 (0.538) in Mexico. The $F$-statistic is above the threshold required to reject the hypothesis that the immigrant influx is a weak instrument in Canada and the United States, but not in Mexico.

25 The elasticity of substitution is more precisely estimated by building in the Autor, Katz, and Kearny (2005) results directly into the calculation. They specify the trend $(t)$ in the United States as $\beta_{1} t+\beta_{2} d t$, where $d$ is a dummy variable indicating an observation after 1992. Rewrite the trend as $\beta_{1}(1+d r) t$, where $r=\beta_{2} / \beta_{1}$. Autor, Katz, and Kearny estimate $r=-0.2$, so that we can redefine the trend variable as increasing at the rate of one per year between 1960 and 1990, and increasing at the rate of 0.8 per year between 1990 and 2000 . The estimate of $1 / \sigma_{E}$ obtained by this method is 0.347 , with a standard error of 0.253 . 
The nature of the nonlinearity in education-specific relative demand shifts in Canada is not well understood. We again introduce splines to allow for different slopes in the trend coefficient for each decade (i.e., the 1970s, the 1980s, and the 1990s). In addition, we allow the trend to have a different intercept in the 1990s, a decade where the Canadian wage structure is perceived to have changed substantially. The introduction of this nonlinearity leads to an estimate of $1 / \sigma_{E}$ that is much more similar to that found in the United States. The estimate reported in row 4 of Table 3 is $0.416(0.137)$, implying an elasticity of substitution across education groups of about 2.4.

The estimated elasticity of substitution across education groups in Mexico is also sensitive to the assumption made about the trend in relative demand shifts of education groups. The analysis of the Mexican data, however, requires additional consideration because there are fewer observations available. The second-stage regression in the Mexican analysis has only 20 observations ( 4 cross-sections and 5 education groups). The introduction of education-specific generalized nonlinear trends would almost exhaust all available degrees of freedom. To allow identification, we instead assume that the structure of relative demand shifts differs mainly between the workers who are high school dropouts (the bulk of the workforce) and all other workers. In effect, we save degrees of freedom by restricting the education-specific trends to be the same for all workers with at least a high school diploma (and allow different trends for each of the two groups of high school dropouts). We then define education-specific linear trends, education-specific splines (starting in 1990), and education-specific shifters in the trend (again beginning in 1990). Row 4 of Table 3 reports the estimated coefficient to be $-0.355(0.099)$, implying an elasticity of substitution across education groups of 2.8. 
Although it is reassuring that the results tend to be more similar across countries once we carefully consider the identification issues regarding relative shifts in demand, we emphasize that the estimates should be interpreted with caution. The shape of the trend used to proxy for changes in relative demand plays a crucial role in the identification of the elasticity of substitution across education groups, and different assumptions about the trend lead to very different estimates of this elasticity. Put bluntly, the assumption that must be made about trends in relative demand shifts in order to estimate $\sigma_{E}$ "may not be innocuous" (Card and Lemieux, 2004, p. 713). Our own experience suggests that the estimated second-stage coefficient (for all three countries) tends to be more negative once we introduce some nonlinearity in the demand shocks. The results summarized in Table 3 , therefore, are representative of a variety of different specifications that lead to roughly similar results.

Further, although this framework offers an empirically tractable approach, the CES specification greatly restricts the types of substitution that can exist among the various factors. For example, the elasticity of substitution across experience groups takes on the same value even though the different cohorts of workers vary widely in their experience; the elasticity of substitution across education groups takes on the same value even though the skill groups vary widely in their education; and the restrictions on the elasticity of substitution between capital and labor do not allow for capital-skill complementarity.

Finally, some studies question the assumption that immigrant and native workers are perfect substitutes within a given skill group (Cortes, 2005; Jaeger, 1996; and Ottaviano and Peri, 2006). It is easy to show that our definition of skill groups is sufficiently narrow that the hypothesis of perfect substitution within a skill cell cannot be rejected. To see this, consider the implied fourth-level CES equation giving the number of workers in each $(s, x, t)$ cell: 


$$
L_{s x t}=\left[\varphi_{s x t} N_{s x t}^{\gamma}+\left(1-\varphi_{s x t}\right) M_{s x t}^{\gamma}\right]^{1 / \gamma}
$$

where $\gamma=1-1 / \sigma_{M N}$, with $\sigma_{M N}$ being the elasticity of substitution between immigrant and native workers in the same skill group (and $-\infty<\gamma \leq 1$ ). The marginal productivity conditions imply:

$$
\log \frac{w_{s x t}^{M}}{w_{s x t}^{N}}=\rho_{s x t}-\frac{1}{\sigma_{M N}} \log \left(\frac{M_{s x t}}{N_{s x t}}\right),
$$

where $w_{s x t}^{M}$ and $w_{s x t}^{N}$ give the wage of immigrant and native workers in cell $(s, x, t)$, respectively; and $\rho_{s x t}=\log \left[\varphi_{s x t} /\left(1-\varphi_{s x t}\right)\right]$. An identifying assumption must be made about the vector $\rho_{s x t}$. Suppose the vector can be approximated by fixed effects indicating a specific educationexperience group, by fixed effects indicating the time period of the observation, and an uncorrelated error term. The estimated coefficient of the relative supply variable in equation (10) is $+0.016(0.015)$ in Canada and $+0.005(0.013)$ in the United States. ${ }^{26}$ Although the coefficients have the wrong sign, the numerical (and statistical) value of the coefficients is effectively zeroimplying that immigrants and natives (within narrowly defined skill groups) are perfect

26 The regressions use weights defined by $\left(n_{M} n_{N} /\left(n_{M}+n_{N}\right)\right)$, where $n_{M}$ and $n_{N}$ are the number of observations used to calculate the mean wage of immigrants and natives, respectively. Our conclusion of a very high elasticity of substitution does not hinge on the identifying assumption made about the vector $\rho_{s x t}$. Suppose that $\rho_{s x t}$ is a constant. We can then simply regress relative wages on relative supplies. The estimate of $1 / \sigma_{M N}$ is $0.030(0.012)$ in Canada and 0.003 (0.006) in the United States. It is worth noting that we were unable to replicate the OttavianoPeri (2006) finding of imperfect substitution in the United States regardless of the identifying restrictions we impose on the vector $\rho_{s x t}$. Hence our results are much more in line with those of Jaeger (1996), who concludes that immigrants and natives are perfect substitutes. We cannot estimate the model in the Mexican data because we do not observe the Mexican earnings of the emigrants. 
substitutes in both countries. We will maintain the assumption of perfect substitution throughout the rest of the analysis.

\subsection{Simulating the Wage Effects of Immigration}

The factor price elasticity giving the impact on the wage of factor $y$ of an increase in the supply of factor $z$ is defined as:

$$
\varepsilon_{y z}=\frac{d \log w_{y}}{d \log L_{z}}=\gamma_{z} \frac{Q_{y z} Q}{Q_{y} Q_{z}} .
$$

where $\gamma_{z}$ is the share of income accruing to factor $z$; and $Q_{y}=\partial Q / \partial L_{y}, Q_{z}=\partial Q / \partial L_{z}$, and $Q_{y z}=$ $\partial^{2} Q / \partial L_{y} \partial L_{z}$. The 3-level CES structure implies that the own factor price elasticity giving the wage impact of an increase in the supply of workers with education $s$ and experience $x$ is:

$$
\varepsilon_{s x, s x}=-\frac{1}{\sigma_{X}}+\left(\frac{1}{\sigma_{X}}-\frac{1}{\sigma_{E}}\right) \frac{\gamma_{s x}}{\gamma_{s}}+\left(\frac{1}{\sigma_{E}}-\frac{1}{\sigma_{K L}}\right) \frac{\gamma_{s x}}{\gamma_{L}}+\frac{1}{\sigma_{K L}} \gamma_{s x},
$$

where $\gamma_{s x}$ gives the share of income accruing to group $(s, x) ; \gamma_{s}$ gives the share of income accruing to education group $s$; and $\gamma_{L}$ gives labor's share of income. The cross factor price elasticity giving the impact on the wage of group $(s, x)$ of an increase in the supply of group $\left(s, x^{\prime}\right.$ ), with $x \neq x^{\prime}$, is

$$
\varepsilon_{s x, s x^{\prime}}=\left(\frac{1}{\sigma_{X}}-\frac{1}{\sigma_{E}}\right) \frac{\gamma_{s x^{\prime}}}{\gamma_{s}}+\left(\frac{1}{\sigma_{E}}-\frac{1}{\sigma_{K L}}\right) \frac{\gamma_{s x^{\prime}}}{\gamma_{L}}+\frac{1}{\sigma_{K L}} \gamma_{s x^{\prime}} .
$$


Finally, the cross factor price elasticity giving the impact on the wage of group $(s, x)$ of an increase in the supply of group $\left(s^{\prime}, x^{\prime}\right)$, with $s \neq s^{\prime}$ and $x^{\prime}=(1, \ldots, x, \ldots 8)$, is

$$
\varepsilon_{s x, s^{\prime} x^{\prime}}=\left(\frac{1}{\sigma_{E}}-\frac{1}{\sigma_{K L}}\right) \frac{\gamma_{s^{\prime} x^{\prime}}}{\gamma_{L}}+\frac{1}{\sigma_{K L}} \gamma_{s^{\prime} x^{\prime}} .
$$

The factor price elasticities depend on the various elasticities of substitution and factor shares. We assume that labor's share of income is 0.62 in Canada, 0.7 in the United States, and 0.67 in Mexico. ${ }^{27}$ We use the latest cross-section available for each of the three countries to apportion the assumed aggregate labor share among the various education-experience groups. ${ }^{28}$

For each country, the simulations use the estimated elasticity of substitution across experience groups obtained in the generalized specification (row 2 in Table 3), and the estimated elasticity of substitution across education groups estimated from the nonlinear trend specification (row 4 in Table 3). The simulations also require an assumption about $\sigma_{K L}$. We use three alternative assumptions: 0.5, 1.0, and 1.5. In the U.S. context, Hamermesh (1993, p. 92) concludes that the aggregate U.S. economy can be reasonably described by a Cobb-Douglas production function, suggesting $\sigma_{K L}$ equals one. Although $\sigma_{K L}$ is often assumed to be 1.0 in Canada, some evidence suggests that it may be closer to 0.5 (Perrier, 2005). Finally, Shah (1992) estimates that $\sigma_{K L}$ is around 0.9 in the Mexican economy.

\footnotetext{
27 These assumptions are based on the estimates of Autor, Katz, and Krueger (1998) for the United States, and International Monetary Fund (2004) for Mexico. We used data on total labor compensation and total value added of the business sector for 1961-2001 to compute the Canadian labor share.

28 We use annual earnings (monthly earnings in the case of Mexico) for men and women to calculate the fraction of all reported earnings accruing to each education-experience cell.
} 
We use the calculated elasticities of factor price to simulate the impact of the flow of international migrants entering (or leaving) a particular country in the 1980-2000 period. The marginal productivity condition for a worker in education group $s$ and experience group $x$ can be written as $w_{s x}=D(K, \mathbf{L})$, where $\mathbf{L}$ is a vector giving the number of workers in each educationexperience group. Suppose initially that the capital stock is constant. The short-run impact of immigration on the log wage of group $(s, x)$ is:

$$
\Delta \log w_{s x}=\sum_{i} \sum_{j} \varepsilon_{s x, i j} m_{i j}
$$

where $m_{s x}$ gives the migrant-induced percent change in labor supply in cell $(s, x)$. Because we are interested in simulating the impact of the cohort that migrated between 1980 and 2000, our simulation of the Canadian and U.S. labor markets defines the supply shock as:

$$
m_{s x}=\frac{M_{s x, 2000}-M_{s x, 1980}}{0.5\left(N_{s x, 1980}+N_{s x, 2000}\right)+M_{s x, 1980}},
$$

so that the baseline population used to calculate the percent increase in labor supply averages out the size of the native workforce during the $1980-2000$ period and treats the pre-existing immigrant population as part of the "native" stock.

We do not have Mexican census data for 1980. Nevertheless, we can calculate the impact of the 1980-2000 emigrant flow because our emigration data is drawn from the U.S. Census. We define the supply shock used in the Mexican simulation as: 


$$
m_{s x}=\frac{M_{s x, 2000}-M_{s x, 1980}}{0.5\left(N_{s x, 1990}+N_{s x, 2000}\right)+\left(M_{s x, 2000}-M_{s x, 1980}\right)},
$$

where we use the average size of the "stayer" workforce (i.e., Mexicans who remained in Mexico) over the 1990-2000 period, and we ignore the emigrants who had left Mexico prior to 1980 in calculating the percent change in labor supply attributable to emigration.

Table 4 summarizes the results of the simulation. Consider initially the top panel, which presents the results for Canada. The first row reports the measure of the supply shock attributable to the 1980-2000 immigrant influx. This immigrant influx increased labor supply by 13.2 percent. The next three rows report the results of the simulation implied by equation (15), where the average percent wage change calculated for each education group is obtained by weighting the predicted impact for each education-experience cell by the income share accruing to that cell.

Regardless of the assumed value of the elasticity of substitution between capital and labor, the short-run simulation reveals that low-skill workers either lost slightly or gained from the immigrant influx, while high-skill workers lost substantially. If we assume that $\sigma_{K L}$ is 1.0 , the simulation reveals that the wage of high school dropouts rose by 2.8 percent, the wage of high school graduates fell by 1.2 percent, and the wage of workers with a post-graduate degree fell by almost 13 percent.

Of course, over time the capital stock adjusts as investors take advantage of the higherthan-normal rental rate of capital. If the capital stock adjusted completely to the immigrant influx, the rental rate would return to its pre-existing level. This alternative counterfactual implies that the long-run impact of immigration on the log wage of group $(s, x)$ is given by: 


$$
\Delta \log w_{s x}=\frac{\gamma_{K}}{\sigma_{K L}} \tilde{K}+\sum_{i} \sum_{j} \varepsilon_{s x, i j} m_{i j}
$$

where $\gamma_{K}$ is capital's share of income; and $\tilde{K}$ is the percent change in the capital stock induced by immigration. The optimal change in the capital stock, $\tilde{K}$, is given by a weighted average of the immigrant supply shocks in the various skill groups, where the weights are the income shares accruing to the various education-experience cells. ${ }^{29}$ Note that equation (17) differs from equation (15) only by a positive constant, $\left(\gamma_{k} / \sigma_{K L}\right) \tilde{K}$. Full capital adjustment mutes the adverse wage impact of immigration but leaves the relative wage effects unchanged. In fact, because the aggregate production function in equation (4) has constant returns, immigration induces a corresponding shift in the capital stock that leaves the capital/labor ratio and the average wage unchanged (where the average wage is the weighted average of the group-specific wage changes in (17), weighted by the group's income share). Moreover, the long-run average effects do not depend on the value of the elasticity of substitution between capital and labor. ${ }^{30}$

The possibility that the capital stock is not constant as immigrants enter the country may be particularly important in the Canadian context, where some visas are granted to independent migrants under the investor category. These investor-immigrants must make investments in Canada. An investor makes a prescribed investment of $\$ 400,000$ payable to the Receiver General of Canada. These funds are allocated to participating provinces and territories in Canada, which

29 To simplify notation, let $\ell$ be the subscript indicating the education-experience skill group. The immigrant-induced change in the capital stock is $\tilde{K}=\sum_{\ell} \gamma_{\ell} m_{\ell} / \gamma_{L}$.

30 The long-run simulation assumes that the rental rate of return to capital adjusts back to what it was in the pre-immigration regime. Other flows of goods and capital may have altered the rate of return to capital in all three countries. We ignore the existence and impact of these flows. 
typically use the funds for job creation and economic development. The full amount of the investment (without interest) is repaid to the investor after approximately five years.

The long-run simulation reported in Table 4 indicates that low-skill workers in Canada have gained substantially from the country's pursuit of an immigration policy that encourages the admission of high-skill workers, while high-skill workers have lost. In particular, the wage of high school dropouts rose by 7.8 percent, while the wage of workers with at least a college education fell by 6 to 8 percent. Put differently, immigration increased the wage of high school dropouts relative to that of college graduates by at least 13 percent.

It is worth emphasizing that the CES technology explicitly assumed that the elasticity of substitution between capital and labor is the same for all labor groups. This assumption contradicts the well-established empirical finding of capital-skill complementarity. Allowing for capital-skill complementarity could have a substantial impact on the Canadian results. The admission of large numbers of high-skill immigrants in Canada would have induced more capital accumulation than allowed for by the model, leading to an even greater damping of the adverse wage effects of immigration for the highly skilled.

As we emphasized earlier, the estimates of the various elasticities of substitution are extremely sensitive to the assumptions made regarding the trend in the relative demand shifts. We evaluate the robustness of the simulation results to these assumptions by instead using the own wage elasticity estimated in the descriptive regressions of Section 5. The regression coefficients reported in Table 1 (from a generic regression of log weekly earnings on the size of the immigrant supply shock and various vectors of fixed effects) indicate that the own wage elasticity in Canada is -0.32 . The "non-structural elasticity" row in Table 4 uses this estimate of the own elasticity and sets all cross-elasticities to zero to simulate the impact of immigration on 
the Canadian wage structure. ${ }^{31}$ The non-structural predictions are very similar to those obtained from the structural model when one assumes that the elasticity of substitution between capital and labor is around 1.0. Although the structural approach provides a more complete picture of how supply shocks propagate themselves through the labor market, the implications of the structural evidence are similar to those of the simpler correlations estimated in Section 5.

It is of interest to compare these predicted wage shifts with what actually happened to the Canadian wage distribution. The bottom row of the top panel reports the change in the (real) log weekly wage of each education group between 1980 and 2000. All education groups suffered a decline in the real wage between 1980 and 2000. It is evident that immigration into Canada cannot explain the differences in relative wage shifts across education groups. There are clearly many other factors that affect the Canadian wage structure and that have been essentially absorbed by the fixed effects included in the regression models. Note, however, that immigration may be a crucial factor in accounting for the disproportionately large drop in real wages suffered by workers with post-graduate degrees. Regardless of the assumption made about the elasticity of substitution, and regardless of whether the simulation is conducted in the short or long run, the immigrant-induced relative wage drop for this group is larger than the real wage drop that actually occurred. Immigration, in effect, prevented the real wage of the most educated workers in Canada from increasing more dramatically, as it did in the United States.

In contrast to the immigrant-induced narrowing of the wage distribution that occurred in Canada, immigration into the United States widened the wage distribution. The 1980-2000 influx increased the average size of the workforce by 11.1 percent, but the supply shock was greater for

\footnotetext{
${ }^{31}$ Because cross-elasticities of factor price are typically very small, the assumption that they are zero is not a gross distortion. In Canada, the cross-elasticity of log weekly wages with respect to shifts in the number of workers in other skill groups is smaller than 0.05 (in absolute value). This evidence is consistent with the full set of cross-elasticities reported in Borjas (2003, p. 1367) for the United States.
} 
low-skill workers. If the elasticity of substitution between capital and labor is 1.0, the short-run simulation reveals that immigration lowered the wage of high school dropouts by 7.1 percent, the wage of workers in the middle of the education distribution by about 2.5 percent, and the wage of workers with at least a college education by nearly 4 percent. These predictions of the structural model closely correspond with those predicted by the non-structural wage elasticity estimated earlier in the paper. In the long run, the simulation indicates a drop of 3.8 percent in the relative wage of high school dropouts, a 1 percent gain in the relative wage of workers in the middle of the education distribution, and a slight reduction in the wage of highly educated workers.

The United States actually experienced a 19.8 percent decline in the real wage of high school dropouts, an 8.2 percent increase in the real wage of college graduates, and a 20.0 percent increase in the wage of workers with a post-graduate education. Therefore, immigration cannot explain the trend in real wages for high-skill workers, but it played an important role in reducing the real wage of low-skill workers. The short-run simulation implies that immigration accounts for about 40 percent of the real wage drop for high school dropouts, while the long-run simulation places the impact of immigration at about 20 percent.

Finally, the Mexican simulation leads to an unexpected conclusion. Even though the 1980-2000 emigrant flow reduced the size of the Mexican workforce by 14.6 percent, and even though most Mexican immigrants in the United States are high school dropouts, the high school dropouts remaining in Mexico did not gain much from this exodus and may lose slightly in the long run! Emigration rates are higher for workers in the middle of the education distribution. As a result, Mexican "stayers" with medium levels of education experienced a substantial increase in real wages. If the elasticity of substitution between capital and labor is 1.0, large-scale 
emigration increased the wage of workers with high school diplomas or some college by over 10 percent in the short run, and increased the wage of high school dropouts by only 4 percent. If the capital stock fully adjusted, Mexican emigration would increase the wage of workers in the middle of the education distribution by 5 to 8 percent, but reduce the wage of high school dropouts by 1 percent. Paradoxically, even though most Mexican immigrants in the United States are high school dropouts, the skill composition of the outflow ends up lowering the relative wage of the high school dropouts remaining in Mexico. The explanation of the paradox lies in the fact that the higher emigration rates of workers with "medium" levels of education makes the skills provided by the high school dropouts remaining in Mexico relatively more abundant.

It is of interest to compare these predicted wage changes with what actually happened in the Mexican labor market between 1990 and 2000 (the 1980 wage data is not available). ${ }^{32}$ The largest real wage increases occurred for workers with the highest education levels, particularly for workers with some college, and the smallest wage increase (particularly in the urban sample that more finely controls for labor supply differences) occurs among high school dropouts. Because many other factors are at work, it is difficult to isolate the role of emigration in the evolution of the wage structure. Nevertheless, it is clear that the outflow of very large numbers of high school dropouts did not increase the relative wage of the low-skill Mexican workforce.

\section{Summary}

One of the central questions in the economics of immigration concerns the impact of immigrants on the labor markets of sending and receiving countries. Economic theory suggests

\footnotetext{
32 The calculation of the actual change in the real wage incorporates the 1000-to-1 Mexican peso devaluation in 1994 and the 477.8 percent inflation rate reported by the Bank of Mexico. Given the large numbers
} 
that, at least in the short run, immigrant-induced shifts in labor supply should lead to oppositesigned changes in the wage of competing workers. This wage response is a crucial parameter not only in the study of the efficiency and distributional impact of international migration, but also in the policy debate over how to best regulate the population flows.

This paper uses microdata drawn from the national censuses of Canada, the United States, and Mexico, and applies the same methodological framework to these data to measure the impact of international migration on the labor market. Perhaps the most important finding is that there is a numerically sizable, statistically significant, and roughly comparable inverse relation between immigrant-induced shifts in labor supply and wages in each of the three countries: A 10 percent labor supply shift is associated with a 3 or 4 percent opposite-signed change in wages.

Despite this similarity, the impact of migration on the wage structure differs significantly across countries. In Canada, international migration narrowed wage inequality because immigrants in Canada tend to be disproportionately high-skill. In the United States, international migration increased wage inequality because immigrants in the United States tend to be disproportionately low-skill. In Mexico, however, emigration rates are highest in the middle of the skill distribution and lowest at the extremes. As a result, international migration has greatly increased relative wages in the middle of the Mexican skill distribution and lowered the relative wages at the extremes. Paradoxically, the large-scale migration of workers from Mexico reduced slightly the relative wage of the low-skill workers remaining in that country.

Our study focused exclusively on the cross-country differences in the distributional impact of international migration. Many questions remain unexamined. It would be interesting to determine if these international differences in distributional impacts have been accompanied by

involved in these adjustments, the numerical value of the percent change in the real wage should be interpreted with caution. The change in relative wages across education groups, however, is invariant to the deflators used. 
sizable differences in the efficiency gains. Further, our analysis ignored the many factors that tie together the labor markets of the three countries. In theory, the flows of international migrants across the three countries - there is, after all a sizable population flow not only from Mexico to the United States, but also from Canada to the United States - should accelerate the process of income convergence in the North American continent. Moreover, the launching of the North American Free Trade Agreement (NAFTA) in January 1994 will influence the rate of income convergence and the size and skill composition of the inter-country population flows. The inclusion of the key variables that tie together these labor markets would greatly increase our understanding not only of a central question in the economics of immigration, but also of the central question in labor economics: how do labor markets work? 


\section{Appendix: Data}

\section{Canada:}

The data are drawn from the 1971, 1981, 1986, 1991, 1996 and 2001 Canadian Census microdata files maintained by Statistics Canada. Each of these confidential data files represents a 20 percent sample of the Canadian population, except for the 1971 file which represents a 33.3 percent sample. Statistics Canada also provides Public Use Microdata Files to Canadian postsecondary institutions and to other researchers. The public use samples represent a much smaller proportion of the Canadian population (e.g., a 2.7 percent sample in 2001). The analysis is restricted to men aged 18-64. A person is classified as an immigrant if he reports being a landed immigrant in the Canadian census, and is either a noncitizen or a naturalized Canadian citizen; all other persons are classified as natives. Sampling weights are used in all calculations.

Definitions of education and experience: We use the Census variables dgreer indicating "highest degree, certificate and diploma" and trnucr indicating "trade or non-university certificate" for the 1981 to 2001 Censuses to classify workers into five education groups: high school dropouts; workers with either a high school diploma or a vocational degree; workers with both a high school and vocational degree or a post-secondary certificate or diploma below Bachelor's degree; Bachelor's degree holders; and post-graduate degree holders. The coding of the relevant variables changes across Censuses. For the 2001 Census these five groups are identified by i) dgreer $=1$ or 11 ; ii) dgreer $=2$ or $($ dgreer $=3$ and trnucr $\neq 5$ and trnucr $\neq 7)$; iii) dgreer $=4$ or dgreer $=5$ or (dgreer $=3$ and trnucr $=5$ or 7$)$; iv $)$ dgreer $=6$; and v) dgreer $=7,8,9$ or 10. The highest degree variable in the 1971 Census only identifies university degree, certificate and diploma holders (and aggregates all others as "not applicable"). We rely on years of grade school (highgrad), vocational training (training), and years of post-secondary education below university (otheredu) to make the 1971 classifications comparable to later Census years. Our construction of the education categories in 1971 assumes that if a worker does not have a Bachelor's degree but has 2 or more years of post-secondary education below university level, that worker possesses a post-secondary certificate or diploma. We also assume that Canadians who have eleven or more years of grade school and were born in Newfoundland or Quebec Provinces are high school graduates. All other Canadian-born and all immigrant men need 12 or more years of grade school to be considered high school graduates. This assumption recognizes the existence of different schooling systems across provinces and assumes that a Canadian-born 
worker's entire grade school education is completed in the province where they were born. Canadian censuses also provide detailed information on the number of years an individual attended grade school (the variable hgradr in the 2000 census), post secondary education below university ( $\left.p s \_o t r\right)$, and university ( $p s \_u v r$ ). We calculate the total years of schooling by adding these variables and define work experience as Age - Years of Education - 6. We restrict the analysis to persons who have between 1 and 40 years of experience. Workers are classified into one of 8 experience groups. The experience groups are defined in five-year intervals (1-5 years of experience, 6-10, 11-15, 16-20, 21-25, 26-30, 31-35, and 36-40).

Counts of persons in education-experience groups: The counts are calculated in the sample of men who do not reside in collective households, have a positive value for weeks worked in the previous calendar year, are not enrolled in school, and are not in the armed forces during the reference week. Because the 1986 census does not provide school attendance information, the construction of the 1986 sample ignores the school enrollment restriction.

Annual and weekly earnings: We use the sample of men who do not reside in collective households, reported positive weeks worked and hours worked (during the reference week), are not in the armed forces in the reference week, and report positive earnings (sum of wages, farmi, and selfi variables, using the variable names corresponding to the 2001 Census). The 1971 census reports weeks worked in the calendar year prior to the survey as a categorical variable. We impute weeks worked for each worker as follows: 7 weeks for 1 to 13 weeks, 20 for 14-26 weeks, 33 for 27-39 weeks, 44 for 40-48 weeks and 50.5 for 49-52 weeks. The average log earnings for a skill cell is defined as the mean of log annual earnings or log weekly earnings over all workers in the relevant population.

Fraction of time worked: We use the sample of men who do not reside in collective households and are not enrolled in school (with the exception of the 1986 Census where school attendance information is not available). The fraction of time worked for each person is defined as the ratio of weeks worked (including zeros) to 52.

\section{United States:}

The data are drawn from the 1960, 1970, 1980, 1990, and 2000 Integrated Public Use Microdata Samples (IPUMS) of the U.S. Census. In the 1960 Census, the data extract forms a 1 percent sample of the population. In the 1970 Census, the extract forms a 3 percent sample 
(obtained by pooling the state, metropolitan area, and neighborhood files). Beginning in 1980, the extracts form a 5 percent sample. The analysis is restricted to men aged 18-64. A person is classified as an immigrant if he was born abroad and is either a non-citizen or a naturalized citizen; all other persons are classified as natives. Sampling weights are used in all calculations.

Definition of education and experience: We use the IPUMS variable educrec to first classify workers into four education groups: high school dropouts (educrec $<=6$ ), high school graduates $($ educrec $=7)$, persons with some college $($ educrec $=8)$, college graduates (educrec $=$ 9 ). The college graduate sample is split into workers with 16 years of schooling or with postgraduate degrees using the variables higrade (in 1960-1980) and educ99 (1990-2000). We assume that high school dropouts enter the labor market at age 17, high school graduates at age 19 , persons with some college at age 21 , college graduates at age 23 , and workers with postgraduate degrees at age 25, and define work experience as the worker's age at the time of the survey minus the assumed age of entry into the labor market. We restrict the analysis to persons who have between 1 and 40 years of experience. Workers are classified into one of 8 experience groups, defined in five-year intervals.

Counts of persons in education-experience groups: The counts are calculated in the sample of men who do not reside in group quarters, have a positive value for weeks worked in the previous calendar year, are not enrolled in school, and are not in the military during the survey week.

Annual and weekly earnings: We use the sample of men who do not reside in group quarters, reported positive weeks worked and hours worked (last week's hours in 1960 and 1970; usual hours in 1980 through 2000), are not in the military in the reference week, and report positive earnings. Our measure of earnings is the sum of the IPUMS variables incwage and incbusfm in 1960, the sum of incwage, incbus, and incfarm in 1970 and 1980, and incearn in 1990-2000. In the 1960-1980 Censuses, the top coded annual salary is multiplied by 1.5. In the 1960 and 1970 Censuses, weeks worked in the calendar year prior to the survey are reported as a categorical variable. We imputed weeks worked for each worker as follows: 6.5 weeks for 13 weeks or less, 20 for 14-26 weeks, 33 for 27-39 weeks, 43.5 for 40-47 weeks, 48.5 for 48-49 weeks, and 51 for 50-52 weeks. The average log earnings for a skill cell is defined as the mean of log annual earnings or log weekly earnings over all workers in the relevant population. 
Fraction of time worked: We use the sample of men who do not reside in group quarters and are not enrolled in school. The fraction of time worked for each person is defined as the ratio of weeks worked (including zeros) to 52 .

\section{Mexico:}

The data are drawn from the 1960, 1970, 1990, and 2000 IPUMS of the Mexican Census. The data extracts from a 1.5 percent sample in the 1960 census, a 1 percent sample in 1970 , a 10 percent sample in 1990, and a 10.6 percent sample in 2000 . The analysis is restricted to men aged 18-64. Sampling weights are used in all calculations.

Definition of education and experience: We use the IPUMS variable edattain to classify workers into the five education groups: high school dropouts with 0-8 years of schooling (educrec $>=110$ and $<=212$ ), high school dropouts with 9-11 years of schooling (educrec $=221$ or 222), high school graduates (edattain $=311$ or 321 ), persons with some college (edattain= 312 or 322 ), and college graduates (edattain $=400$ ). Our definition implies that the sample of high school dropouts with 0-8 years of schooling contains workers who have, at best, completed primary education. The sample of high school dropouts with 9-11 years of schooling contains workers who completed primary school but have less than a secondary education. The sample of high school graduates contains those who completed only their secondary general track education or those who obtained a secondary technical degree. The sample of workers with some college includes workers who completed their secondary general track and report having some college or university, or who completed their secondary technical track and have a postsecondary technical degree. The sample of college graduates includes workers who report having completed a university education. Workers who do not report a valid value for the educational attainment variable are excluded from the analysis. There are some inconsistencies in our coding of education classification for workers who report completing a primary education, but less than a secondary education in a technical track. We recoded these workers as being high school dropouts with 0-8 years of school if they did not attend school for at least 9 years. There are also some inconsistencies for workers who report completing a secondary technical degree. Some of these workers report attending school for much fewer than 12 years, while others report attending school for much more than 12 years. We reclassified workers who report completing a secondary technical degree as high school dropouts if they attended school for less than 11 years, 
and reclassified them as "some college" if they attended school for more than 13 years. We assume that high school dropouts enter the labor market at age 17, high school graduates at age 19 , persons with some college at age 21 , and college graduates at age 23 , and define work experience as the worker's age at the time of the survey minus the assumed age of entry into the labor market. We restrict the analysis to persons who have between 1 and 40 years of experience. Workers are classified into one of 8 experience groups, defined in five-year intervals.

Counts of persons in education-experience groups: The counts of workers who remained in Mexico are calculated in the sample of men who are at work (the IPUMS employment status variable empstat $=1100)$, report a positive value for monthly income, and are not enrolled in school. The counts of emigrants are obtained from the U.S. Census using the same restrictions described above in our discussion of the U.S. data, with the caveat that the emigrants must be persons who are immigrants and born in Mexico. The 1960 census does not report the variable empstat nor does it report a person's school enrollment status. The sample of workers in 1960 is then composed of persons who report a positive value for monthly earnings.

Monthly earnings: The variable gives the total monthly earnings (both salary and selfemployment income) in 1960, 1990, and 2000, and the total monthly income in 1970. We exclude persons who are not "at work" and do not report a valid, positive value for monthly earnings. In each census, the top-coded monthly earnings are multiplied by 1.5. The average log earnings for a skill cell is defined as the mean of log monthly over all workers in the relevant population.

Labor force participation rate: We use the sample of men who provide a valid answer for their employment status variable (empstat). We define a labor force participant as someone who is either working or unemployed (i.e., someone who is not "inactive"). This variable is only available in the 1970, 1990 and 2000 cross-sections. 


\section{References}

Altonji, Joseph G. and David Card (1991). "The Effects of Immigration on the Labor Market Outcomes of Less-Skilled Natives.” In Immigration, Trade, and the Labor Market, edited by John M. Abowd and Richard B. Freeman. University of Chicago Press.

Autor, David H., Lawrence F. Katz, and Melissa S. Kearney (2005). “Trends in U.S. Wage Inequality: Re-Assessing the Revisionists.” Working Paper, National Bureau of Economic Research.

Autor, David H., Lawrence F. Katz, and Alan B. Krueger (1998). “Computing Inequality: Have Computers Changed the Labor Market?” Quarterly Journal of Economics, 117, 11691213.

Aydemir, Abdurrahman and George J. Borjas (2005). “Attenuation Bias in Estimating the Wage Impact of Immigration.” Working Paper, Harvard University.

Beaudry, Paul and David Green (2000). "What Is Driving US and Canadian Wages? Exogenous Technical Change or Endogenous Choice of Technique.” Working Paper, University of British Columbia.

Bohn, Sarah and Seth Sanders (2005). “Refining the Estimation of Immigration's Labor Market Effects.” Working Paper, University of Maryland.

Bonin, Holger (2005). "Is the Demand Curve Really Downward Sloping?” Working Paper, IZA. Borjas, George J. (1987). “Immigrants, Minorities, and Labor Market Competition.” Industrial and Labor Relations Review, 40, 382-392.

Borjas, George J. (2003). “The Labor Demand Curve Is Downward Sloping: Reexamining the Impact of Immigration on the Labor Market." Quarterly Journal of Economics, 118, $1335-1374$. 
Borjas, George J. (2006). "Native Internal Migration and the Labor Market Impact of Immigration." Journal of Human Resources, 41, 221-258.

Borjas, George J., Richard B. Freeman, and Lawrence F. Katz (1997). "How Much Do Immigration and Trade Affect Labor Market Outcomes?" Brookings Papers on Economic Activity, 1, 1-67.

Boudarbat, Brahim, Thomas Lemieux, and W. Craig Riddell (2003). "Recent Trends in Wage Inequality and the Wage Structure in Canada.” Working Paper, University of British Columbia.

Bowles, Samuel (1970). “Aggregation of Labor Inputs in the Economics of Growth and Planning: Experiments with a Two-Level CES Function." Journal of Political Economy, $78,68-81$.

Caponi, Vincenzo (2004). "Heterogeneous Human Capital and Migration: Who Migrates from Mexico to the US?" Working Paper, University of Western Ontario.

Card, David (1990). "The Impact of the Mariel Boatlift on the Miami Labor Market." Industrial and Labor Relations Review 43 (January 1990): 245-257.

Card, David (2001). "Immigrant Inflows, Native Outflows, and the Local Labor Market Impacts of Higher Immigration.” Journal of Labor Economics, 19, 22-64.

Card, David, and Thomas Lemieux (2001). "Can Falling Supply Explain the Rising Return to College for Younger Men? A Cohort-Based Analysis." Quarterly Journal of Economics, $116,705-746$.

Chiquiar, Daniel, and Gordon H. Hanson (2005).'International Migration, Self-Selection, and the Distribution of Wages: Evidence from Mexico and the United States," Journal of Political Economy, 113, 239-281. 
Citizenship and Immigration Canada (2001). Facts and Figures: Immigration Overview, 2001.

Cortes, Patricia (2005). “The Effect of Low-Skilled Immigration on U.S. Prices: Evidence from CPI Data.” Working Paper, Massachusetts Institute of Technology.

Filer, Randall K. (1992). “The Impact of Immigrant Arrivals on Migratory Patterns of Native Workers." In Immigration and the Work Force: Economic Consequences for the United States and Source Areas, edited by George J. Borjas and Richard B. Freeman. University of Chicago Press.

Frey, William (1995). "Immigration Impacts on Internal Migration of the Poor: 1990 Census Evidence for U.S. States." International Journal of Population Geography, 1, 51-67. Grossman, Jean Baldwin (1982). "The Substitutability of Natives and Immigrants in Production." Review of Economics and Statistics, 54, 596-603.

Hamermesh, Daniel (1993). Labor Demand. Princeton University Press.

Hanson, Gordon H. (2006). “Emigration, Labor Supply, and Earnings in Mexico.” In Mexican Immigration, edited by George J. Borjas. University of Chicago Press, forthcoming. Ibarraran, Pablo and Darren Lubotsky. (2006). "Mexican Immigration and Self-Selection: New Evidence from the 2000 Mexican Census." In Mexican Immigration, edited by George J. Borjas. University of Chicago Press, forthcoming.

International Monetary Fund (2004). “Mexico: Selected Issues.” IMF Country Report No. $04 / 418$.

Jaeger, David (1996). "Skill Differences and the Effect of Immigrants on the Wages of Natives," Working Paper, U.S. Bureau of Labor Statistics.

Katz, Lawrence F., and Kevin M. Murphy (1992). "Changes in the Wage Structure, 1963-87: Supply and Demand Factors." Quarterly Journal of Economics, 107, 35-78. 
Lewis, Ethan (2005). "Immigration, Skill Mix, and the Choice of Technique.” Working Paper, Federal Reserve Bank of Philadelphia.

Mishra, Prachi (2005). "Emigration and Wages in Source Countries: Evidence from Mexico." Journal of Development Economics, forthcoming.

Ottaviano, Gianmarco I.P. and Giovanni Peri (2006). "Rethinking the Gains from Immigration: Theory and Evidence from the U.S.” Working Paper, University of California, Davis.

Passel, Jeffrey (2005). "Unauthorized Migrants: Number and Characteristics.” Working Paper, Pew Hispanic Center.

Perrier, Patrick (2005). "Le fonction de production et les données Canadiennes.” Working Paper. Bank of Canada.

Roy, Arun S. (1997). "Job Displacement Effects of Canadian Immigrants by Country of Origin and Occupation." International Migration Review, 31, 150-161.

Shah, Anwar (1992). "Dynamics of Public Infrastructure, Industrial Productivity and Profitability." Review of Economics and Statistics, 74, 28-36.

United Nations (2002). International Migration, 2002. Population Division, Department of Economics and Social Affairs.

U.S. Department of Homeland Security (2004). 2003 Yearbook of Immigration Statistics. Office of Immigration Statistics.

Welch, Finis (1979). "Effects of Cohort Size on Earnings: The Baby Boom Babies' Financial Bust.” Journal of Political Economy, 87, S65-S97. 
Figure 1. Trends in the immigrant/emigrant share for male workers, by country

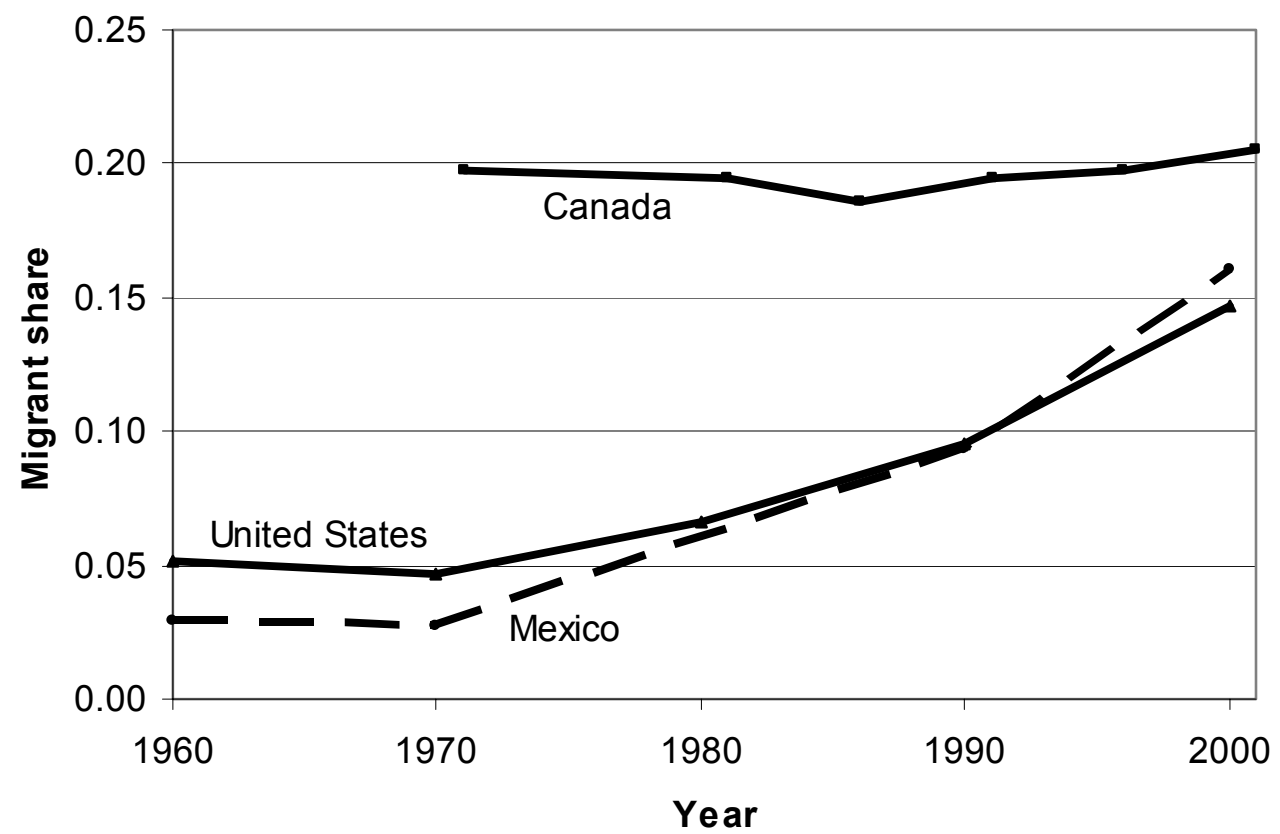

Notes: The trend lines for Canada and the United States give the fraction of the workforce that is foreign-born; the trend line for Mexico gives the fraction of the Mexican workforce that emigrated to the United States. 


\section{Figure 2. Trends in the immigrant/emigrant share for male workers, by education and country}

\section{Canada:}

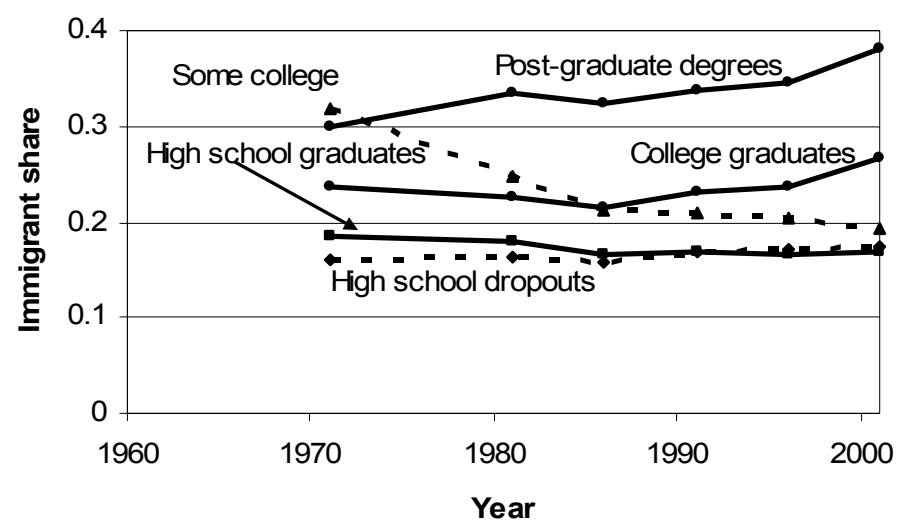

\section{United States:}

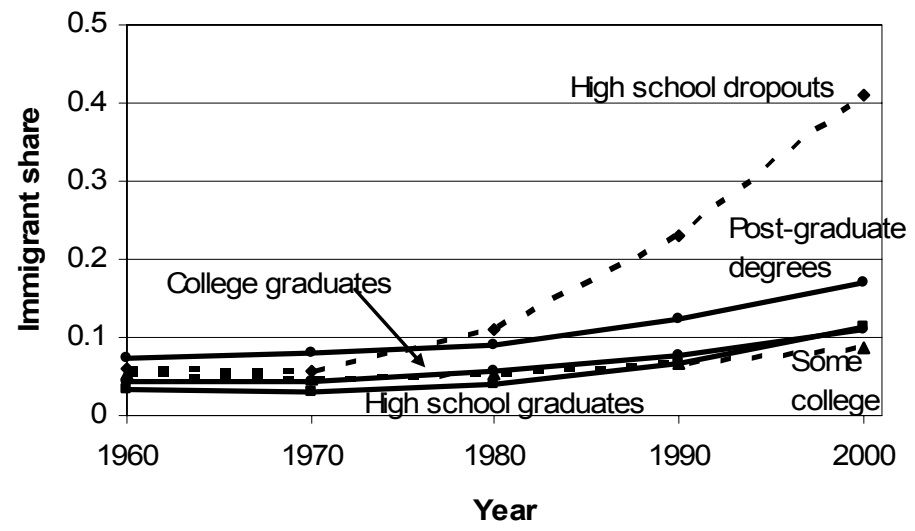

Mexico:

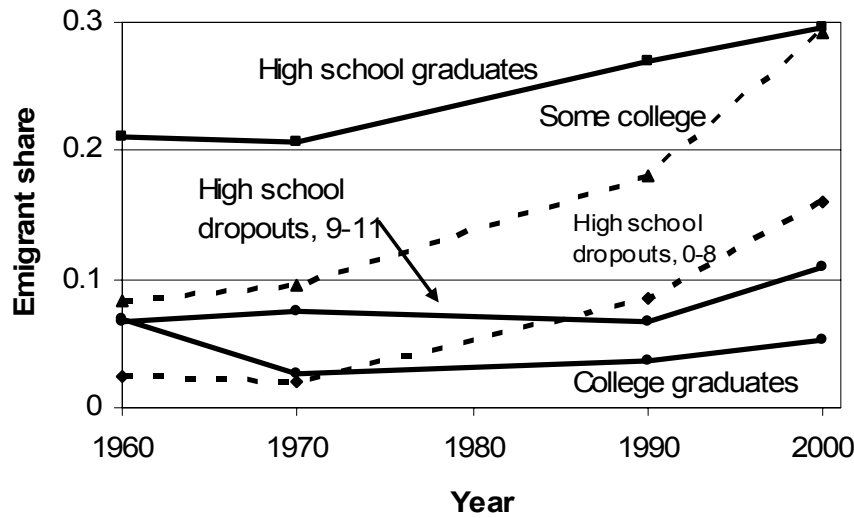

Notes: The trend lines for Canada and the United States give the fraction of the workforce that is foreign-born; the trend line for Mexico gives the fraction of the Mexican workforce that emigrated to the United States. 
Figure 3 - The immigrant supply shock in Canada, 1971-2001

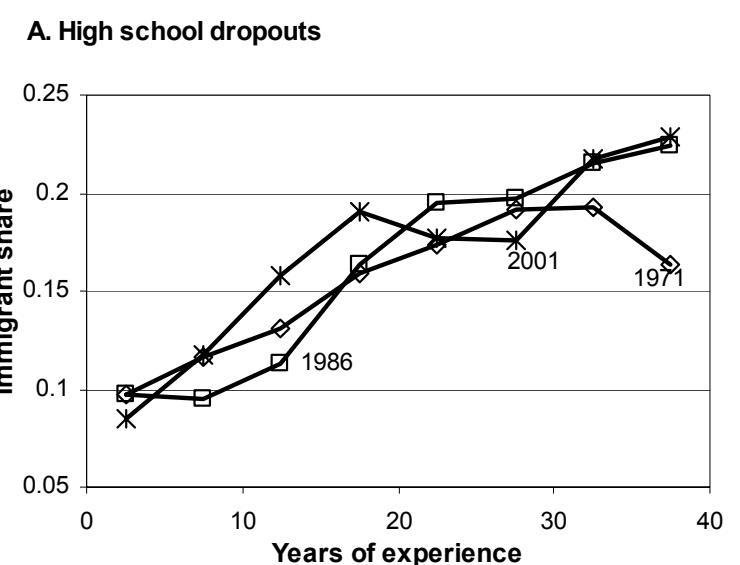

B. Either high school or vocational degree

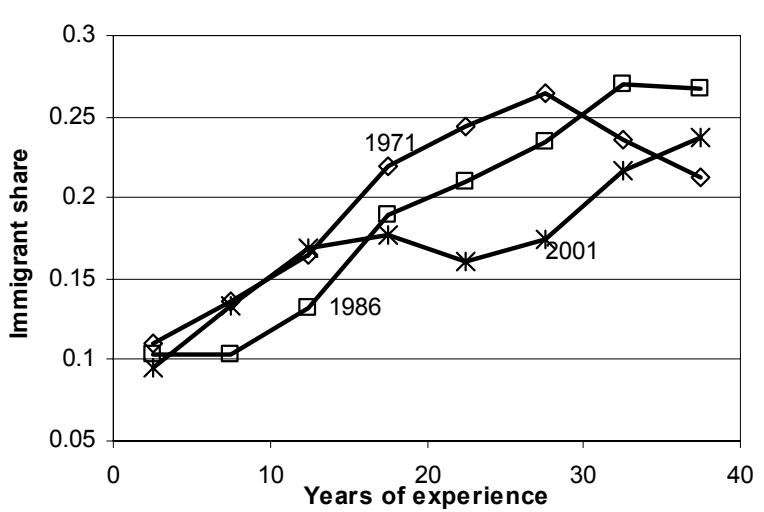

E Post-graduate degree

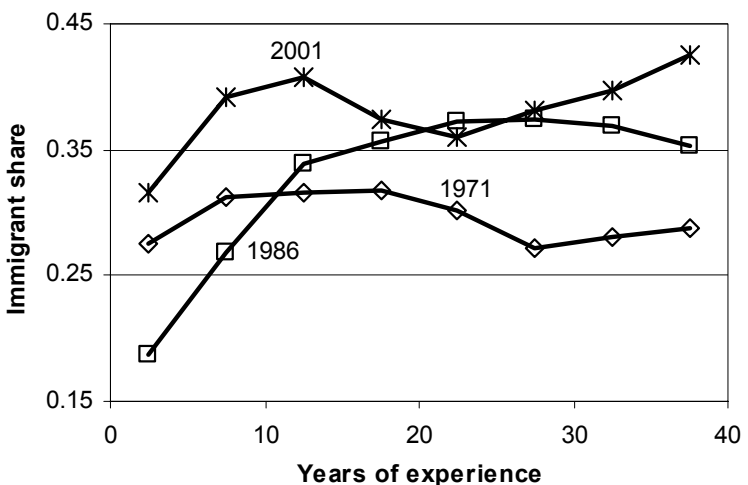

\section{Both high school and vocational degree}

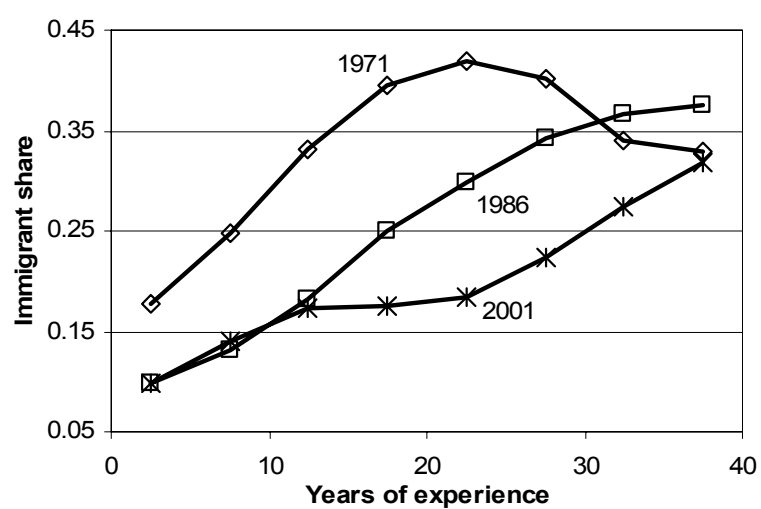

D. Bachelor's degree

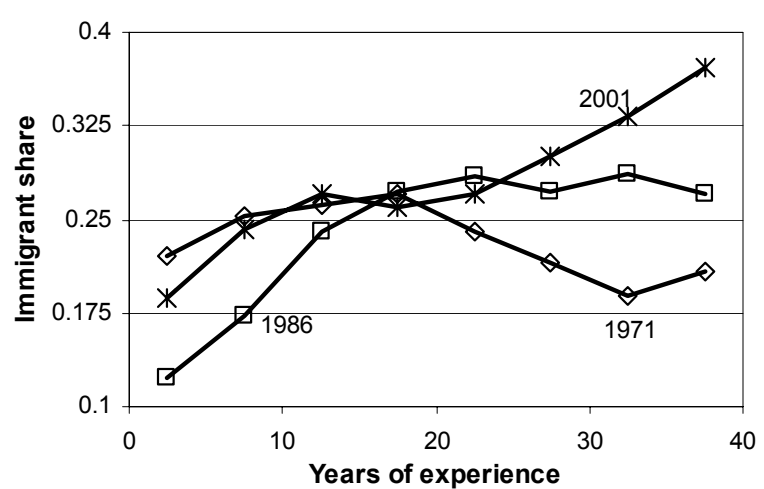

Note: The immigrant share gives the fraction of the workforce that is foreign-born in a particular education-experience group. 
Figure 4. The immigrant supply shock in the United States, 1960-2000

A. High school dropouts

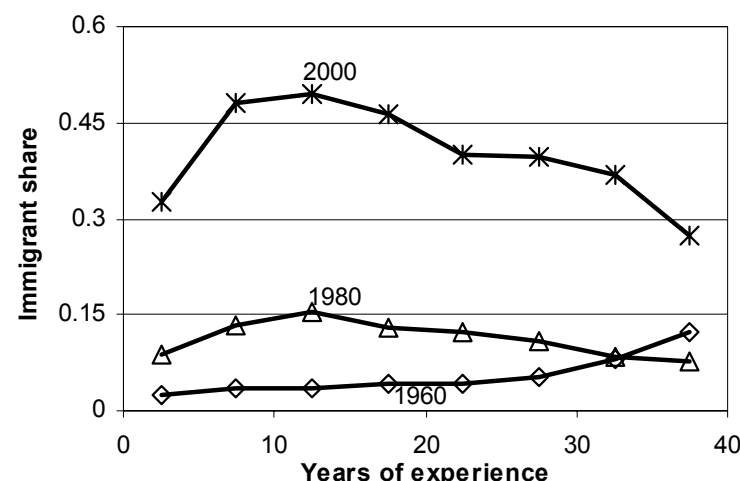

D. College graduates

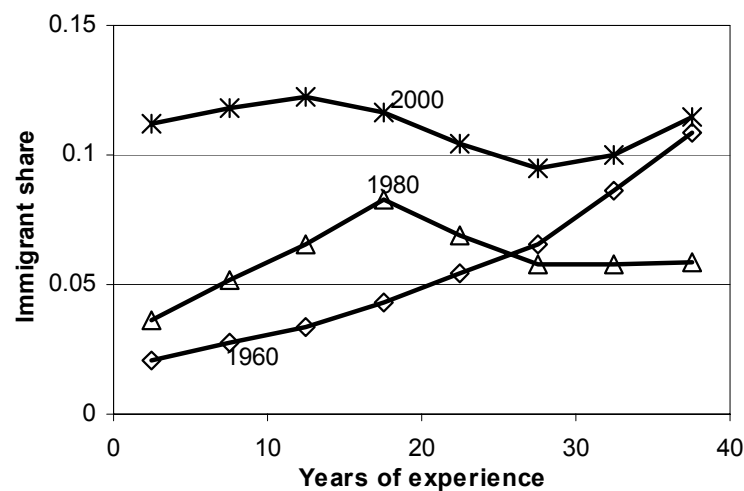

B. High school graduates

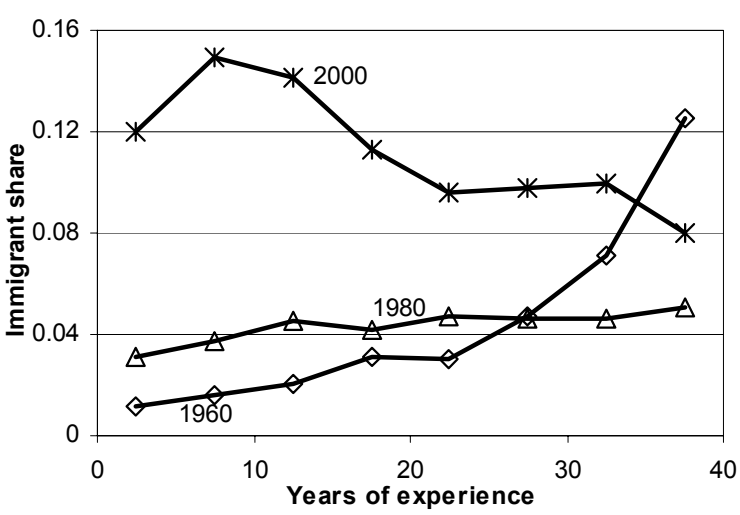

E Post-graduate degree

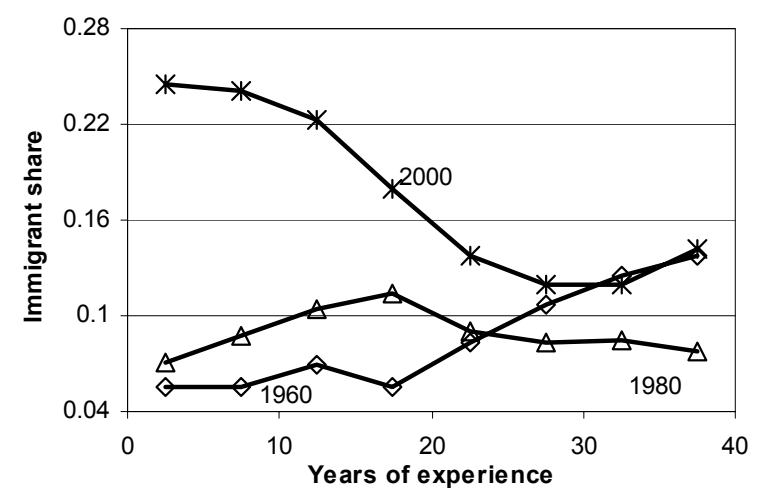

C. Some college

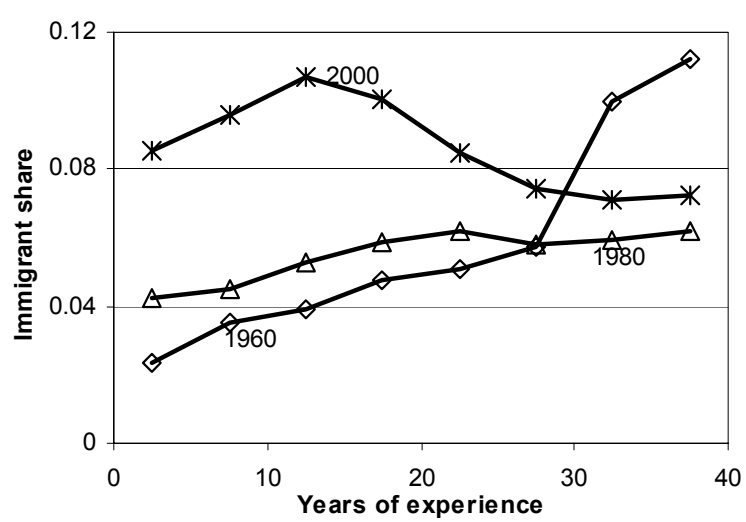

Note: The immigrant share gives the fraction of the workforce that is foreign-born in a particular education-experience group. 
Figure 5. The emigrant supply shock in Mexico, 1960-2000

A. 0-8 years of schooling

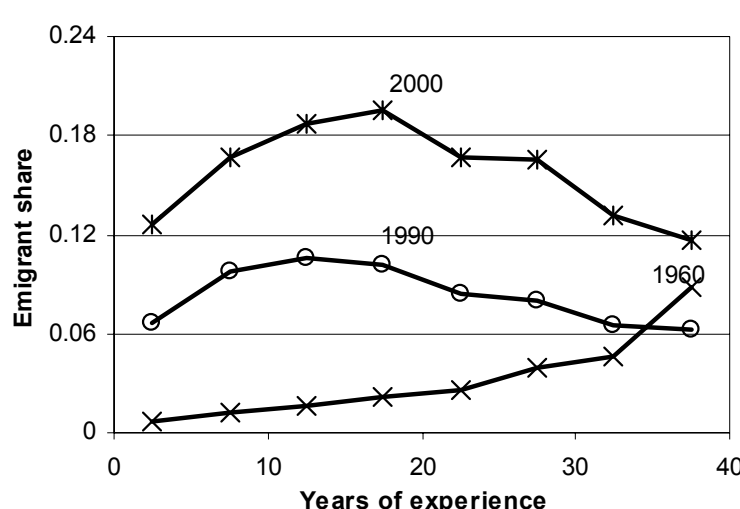

D. Some college

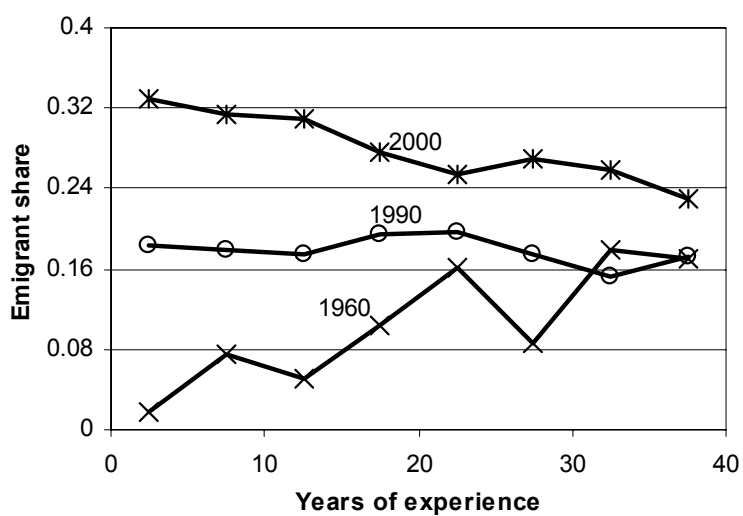

B. 9-11 years of schooling

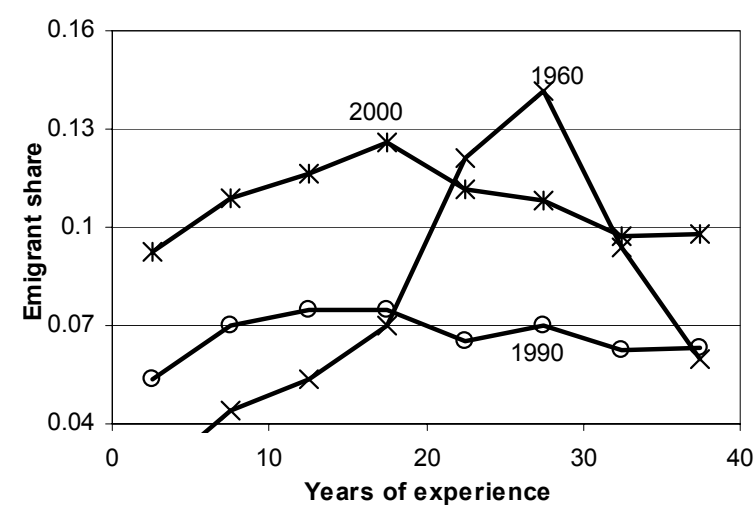

E College graduates

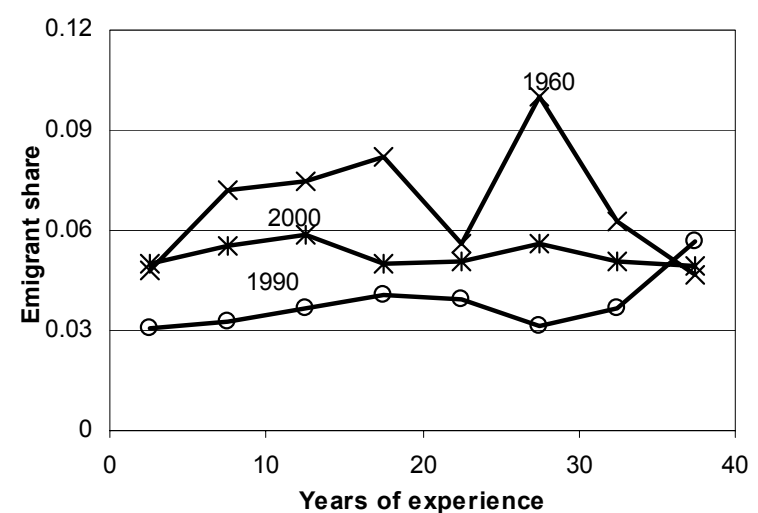

C. High school graduates

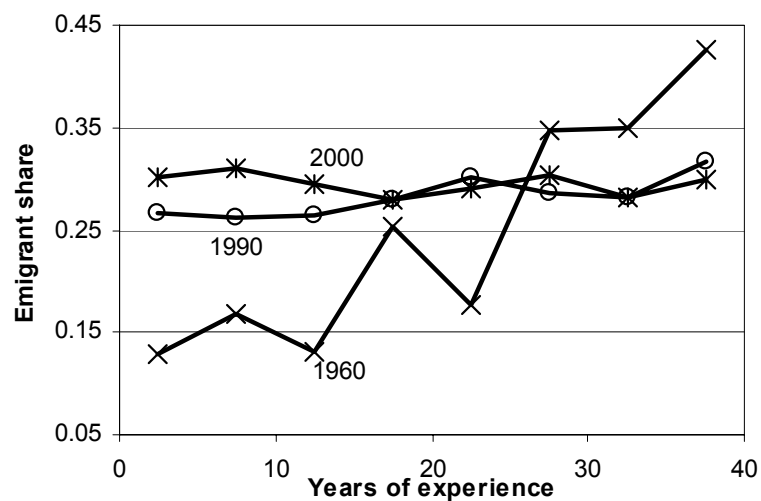




\section{Figure 6. Trends in the relative wage of college graduates, by years of experience}

\section{Canada:}

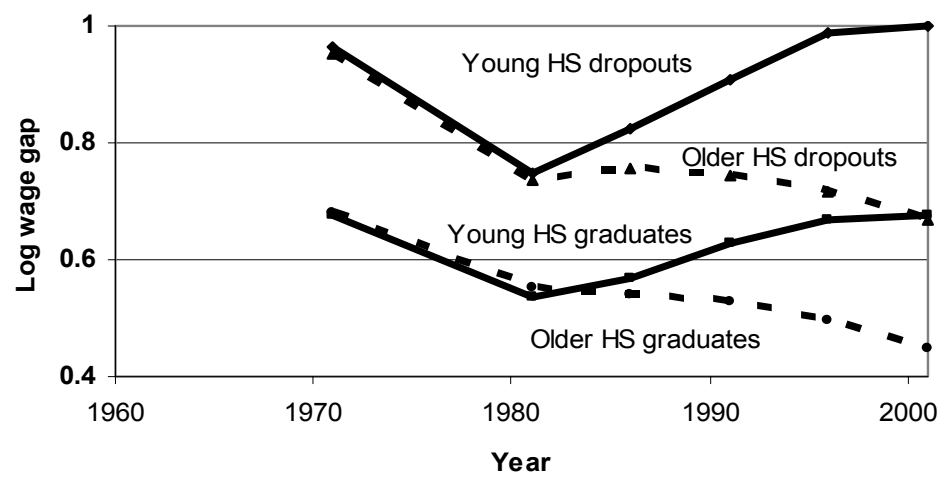

\section{United States:}

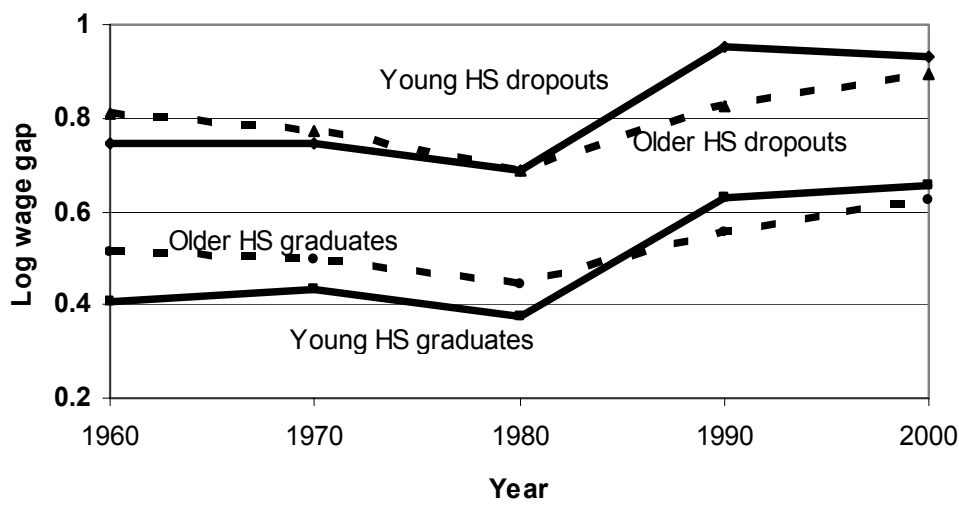

Mexico:

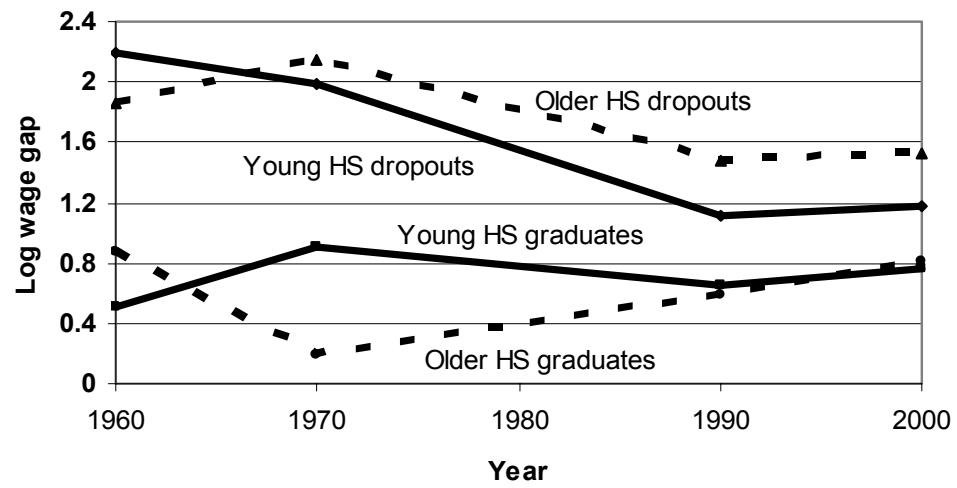

Notes: The figures illustrate the log weekly wage gap between college graduates and the respective education groups. The "young" group of workers has 6 to 10 years of experience; the older group has 31 to 35 years. In this figure, the college graduate sample in the Canadian and U.S. data includes all persons who have at least a college degree, and the high school dropout sample in Mexico includes all persons with less than 12 years of schooling. 
Table 1. Relation between the immigrant/emigrant share and labor market outcomes.

\section{Weighted Regressions}

1. Canada

2. United States

Mexico

\begin{tabular}{ccc}
\multicolumn{3}{c}{ Earnings outcomes } \\
\hline Log & Log & Log \\
annual & weekly & monthly \\
earnings & earnings & earnings \\
\hline
\end{tabular}

Employment outcomes
$-0.617$

(0.246)

$-0.845$

(0.472)
$-0.507$

(0.202)

$-0.489$

(0.223)

$\begin{array}{cc}\text { Fraction of } & \text { Labor force } \\ \text { weeks } & \text { participation } \\ \text { worked } & \text { rate }\end{array}$

$-0.241$

(0.108)

$-0.345$

(0.075)

\section{All workers}
4. All workers, 1990-2000
5. Urban workers
3. All workers
$\begin{array}{ll}-- & -- \\ -- & - \\ -- & -\end{array}$
0.798
$---$
0.058
$(0.443)$
0.841
0.062
$(0.540)$
0.652
0.065
$(0.419)$

Notes: Standard errors are reported in parentheses and are adjusted for clustering within education-experience cells. All coefficients are obtained from regressions weighted by the sample size used to compute the dependent variable. For Canada and the United States, the table reports the coefficient of the immigrant share variable from regressions where the dependent variable is the mean labor market outcome of native-born persons in an education-experience group at a particular point in time. For Mexico, the table reports the coefficient of the emigrant share variable from regressions where the dependent variable is the mean labor market outcome of Mexican stayers in an educationexperience group at a particular point in time. The regressions estimated in Canada have 240 observations; the regressions estimated in the United States have 200 observations; the wage regressions estimated in Mexico have 160 observations in rows 3 and 5 , and 80 observations in row 4; and the labor force participation regressions estimated in Mexico have 120 observations in rows 3 and 5, and 80 observations in row 4 . All regression models include education, experience, and period fixed effects, as well as interactions between education and experience fixed effects, education and period fixed effects, and experience and period fixed effects. 


\section{Table 2. Sensitivity analysis of the relation between wages and the immigrant/emigrant share}

Sample:

1. Baseline (from table 1)

2. Includes women in measure of immigrant supply shock

3. Includes men and women in skill group

4. Salaried workers only

5. Omits workers with less than 5 years or more than 35 years of experience

6. Uses 10-year grouping for experience

7. Uses four education groups, pools college graduates in Canada and U.S.; pools high school dropouts in Mexico

8. Omits high school dropouts

9. Omits workers with 8 or fewer years of schooling

10. Omits college graduates

11. Omits workers with post-graduate degrees

12. Adjusts education of persons who migrated from Mexico as children

\begin{tabular}{|c|c|c|c|c|}
\hline \multicolumn{2}{|c|}{ Canada } & \multicolumn{2}{|c|}{ United States } & Mexico \\
\hline $\begin{array}{c}\text { Log } \\
\text { annual } \\
\text { earnings }\end{array}$ & $\begin{array}{c}\text { Log } \\
\text { weekly } \\
\text { earnings } \\
\end{array}$ & $\begin{array}{c}\text { Log } \\
\text { annual } \\
\text { earnings } \\
\end{array}$ & $\begin{array}{c}\text { Log } \\
\text { weekly } \\
\text { earnings } \\
\end{array}$ & $\begin{array}{c}\text { Log } \\
\text { monthly } \\
\text { earnings }\end{array}$ \\
\hline-0.617 & -0.507 & -0.845 & -0.489 & 0.798 \\
\hline$(0.246)$ & $(0.202)$ & $(0.472)$ & $(0.223)$ & $(0.443)$ \\
\hline-0.766 & -0.642 & -0.999 & -0.672 & 0.882 \\
\hline$(0.229)$ & $(0.191)$ & $(0.576)$ & $(0.221)$ & $(0.382)$ \\
\hline-0.679 & -0.510 & -0.923 & -0.865 & 0.440 \\
\hline$(0.195)$ & $(0.149)$ & $(0.606)$ & $(0.785)$ & $(0.326)$ \\
\hline-0.518 & -0.398 & -0.755 & -0.414 & 0.377 \\
\hline$(0.222)$ & $(0.173)$ & $(0.409)$ & $(0.180)$ & $(0.362)$ \\
\hline-0.678 & -0.567 & -0.822 & -0.313 & 0.724 \\
\hline$(0.158)$ & $(0.147)$ & $(0.416)$ & $(0.271)$ & $(0.430)$ \\
\hline-0.555 & -0.487 & -1.231 & -0.596 & 0.853 \\
\hline$(0.474)$ & $(0.378)$ & $(0.835)$ & $(0.472)$ & $(0.708)$ \\
\hline-0.654 & -0.561 & -1.112 & -0.643 & 1.204 \\
\hline$(0.248)$ & $(0.198)$ & $(0.527)$ & $(0.227)$ & $(0.347)$ \\
\hline-0.769 & -0.668 & -0.101 & 0.078 & --- \\
\hline$(0.171)$ & $(0.145)$ & $(0.606)$ & $(0.458)$ & \\
\hline-0.608 & -0.506 & -0.600 & -0.209 & --- \\
\hline$(0.215)$ & $(0.182)$ & $(0.468)$ & $(0.310)$ & \\
\hline-0.081 & 0.001 & -0.910 & -0.575 & --- \\
\hline$(0.403)$ & $(0.318)$ & $(0.445)$ & $(0.148)$ & \\
\hline-0.535 & -0.423 & -1.134 & -0.713 & --- \\
\hline$(0.301)$ & $(0.247)$ & $(0.486)$ & $(0.197)$ & \\
\hline --- & --- & --- & --- & $\begin{array}{c}0.675 \\
(0.507)\end{array}$ \\
\hline
\end{tabular}

Notes: Standard errors are reported in parentheses and are adjusted for clustering within education-experience cells. All coefficients are obtained from regressions weighted by the sample size used to compute the dependent variable. For Canada and the United States, the table reports the coefficient of the immigrant share variable from regressions where the dependent variable is the mean log weekly or log annual earnings of native-born persons in an educationexperience group at a particular point in time. For Mexico, the table reports the coefficient of the emigrant share variable from regressions where the dependent variable is the mean log monthly earnings of Mexican stayers in an education-experience group at a particular point in time. All regression models include education, experience, and period fixed effects, as well as interactions between education and experience fixed effects, education and period fixed effects, and experience and period fixed effects. 


\section{Table 3. Estimates of elasticities of substitution from the CES model}

First stage, estimates $-1 / \sigma_{X}$ 1. Simple specification

2. Generalized specification

Second stage, estimates $-1 / \sigma_{E}$ 3. Linear trend

4. Nonlinear trend

\begin{tabular}{ccc} 
Canada & United States & Mexico \\
\hline-0.030 & -0.321 & -0.286 \\
$(0.015)$ & $(0.120)$ & $(0.136)$
\end{tabular}

$-0.135$

$-0.122$

$-0.234$

(0.037)

$(0.038)$

$(0.072)$

$-0.273$

$-0.416$

$-0.327$

$-0.355$

$(0.137)$

(0.379)

Notes: Robust standard errors are reported in parentheses. The standard errors reported in rows 1 and 2 are adjusted for clustering within education-experience cells. The dependent variable is log weekly earnings in Canada and the United States, and log monthly earnings in Mexico. All coefficients are obtained from regressions weighted by the sample size used to compute the dependent variable. The first (second) stage regressions have 240 (30) observations in Canada, 200 (25) observations in the United States, and 160 (20) observations in Mexico. The "generalized specification" in row 2 adds a linear trend interacted with experience fixed effects. The "nonlinear trend" in Canada includes the education-specific linear trend variables and education-specific splines for the 1980s and the 1990s. The nonlinear trend in the United States includes the education-specific linear trend between 1960 and 2000 and an education-specific spline in the trend line for the 1990s. The nonlinear trend in Mexico includes an educationspecific linear trend between 1960 and 2000 and an education-specific spline in the trend line for the 1990s. All second-stage regressions in all countries include education-specific shifters for the 1990s to allow for possible level breaks in the trends. To conserve degrees of freedom, the Mexican analysis reported in row 4 allows the educationspecific trend lines to vary only among three groups: high school dropouts with 0 to 8 years of schooling, high school dropouts with 9 to 11 years of schooling, and all other workers. 
Table 4. Predicted percent wage impacts of 1980-2000 immigrant/emigrant supply shock

\begin{tabular}{|c|c|c|c|c|c|c|}
\hline & $\begin{array}{l}\text { High } \\
\text { school } \\
\text { dropouts }\end{array}$ & $\begin{array}{c}\text { High } \\
\text { school } \\
\text { graduates }\end{array}$ & $\begin{array}{c}\text { Some } \\
\text { college }\end{array}$ & $\begin{array}{l}\text { College } \\
\text { graduates }\end{array}$ & $\begin{array}{l}\text { Post- } \\
\text { graduate } \\
\text { degree }\end{array}$ & $\begin{array}{c}\text { All } \\
\text { workers }\end{array}$ \\
\hline \multicolumn{7}{|l|}{ Canada } \\
\hline Supply shock (\%) & 5.6 & 4.1 & 13.8 & 27.1 & 31.9 & 13.2 \\
\hline Short-run, $\sigma_{K L}=0.5$ & -2.2 & -6.3 & -10.3 & -15.8 & -17.8 & -10.1 \\
\hline Short-run, $\sigma_{K L}=1.0$ & 2.8 & -1.2 & -5.3 & -10.8 & -12.8 & -5.0 \\
\hline Short-run, $\sigma_{K L}=1.5$ & 4.5 & 0.4 & -3.6 & -9.1 & -11.1 & -3.4 \\
\hline Long-Run & 7.8 & 3.8 & -0.2 & -5.8 & -7.8 & 0.0 \\
\hline Non-structural elasticity & 1.8 & -1.3 & -4.4 & -8.7 & -10.2 & -4.2 \\
\hline Actual \% wage change & -19.3 & -16.2 & -8.7 & -2.2 & -7.0 & -6.1 \\
\hline \multicolumn{7}{|l|}{ United States } \\
\hline Supply shock (\%) & 22.8 & 8.1 & 9.2 & 12.0 & 12.8 & 11.1 \\
\hline Short-run, $\sigma_{K L}=0.5$ & -10.5 & -5.7 & -6.0 & -6.9 & -7.2 & -6.6 \\
\hline Short-run, $\sigma_{K L}=1.0$ & -7.1 & -2.3 & -2.7 & -3.6 & -3.9 & -3.3 \\
\hline Short-run, $\sigma_{K L}=1.5$ & -6.0 & -1.2 & -1.6 & -2.5 & -2.8 & -2.2 \\
\hline Long run & -3.8 & 1.0 & 0.6 & -0.3 & -0.6 & 0.0 \\
\hline Non-structural elasticity & -8.2 & -2.9 & -3.3 & -4.3 & -4.6 & -4.0 \\
\hline \multirow[t]{2}{*}{ Actual \% wage change } & -19.8 & -14.8 & -4.1 & 8.2 & 20.0 & 1.7 \\
\hline & $\begin{array}{c}\text { Dropouts, } \\
0-8 \text { yrs }\end{array}$ & $\begin{array}{c}\text { Dropouts, } \\
9-11 \text { yrs }\end{array}$ & $\begin{array}{c}\text { High } \\
\text { school } \\
\text { graduates }\end{array}$ & $\begin{array}{l}\text { Some } \\
\text { college }\end{array}$ & $\begin{array}{l}\text { College } \\
\text { graduates }\end{array}$ & $\begin{array}{c}\text { All } \\
\text { workers }\end{array}$ \\
\hline Supply shock (\%) & -11.6 & -11.6 & -35.6 & -29.7 & -5.8 & -14.6 \\
\hline Short-run, $\sigma_{K L}=0.5$ & 8.6 & 8.6 & 17.1 & 15.0 & 6.5 & 9.6 \\
\hline Short-run, $\sigma_{K L}=1.0$ & 3.8 & 3.8 & 12.3 & 10.2 & 1.7 & 4.8 \\
\hline Short-run, $\sigma_{K L}=1.5$ & 2.2 & 2.2 & 10.7 & 8.6 & 0.1 & 3.2 \\
\hline Long run & -1.0 & -1.1 & 7.5 & 5.4 & -3.1 & 0.0 \\
\hline Non-structural elasticity & 6.5 & 6.5 & 19.9 & 16.6 & 3.3 & 8.2 \\
\hline $\begin{array}{l}\text { Actual \% wage change, } \\
\text { 1990-2000 }\end{array}$ & 10.7 & 3.0 & 7.0 & 24.7 & 18.7 & 16.1 \\
\hline $\begin{array}{l}\text { Actual \% wage change } \\
\text { in urban sample, 1990- } \\
2000\end{array}$ & 4.7 & 3.8 & 7.5 & 23.7 & 18.0 & 13.8 \\
\hline
\end{tabular}

Notes: The simulation uses the elasticity of substitution across experience groups reported in row 2 of Table 3 , and the elasticity of substitution across education groups reported in row 4 of Table 3 . The "non-structural elasticity" predictions use the own wage elasticity estimated in Table 1 ( -0.32 for Canada, -0.36 for the United States, and -0.56 for Mexico), and sets all cross-elasticities equal to zero. The variable measuring the group-specific immigrant supply shock in Canada and the United States is defined as the number of immigrants arriving between 1980 and 2000 divided by a baseline population equal to the average size of the native workforce (over 1980-2000) plus the number of immigrants in 1980. The variable measuring the emigrant supply shock in Mexico is defined as the number of persons who emigrated between 1980 and 2000 divided by a baseline native population equal to the average size of the Mexican stayer workforce (over 1990-2000) plus the number of persons who emigrated between 1980 and 2000. We used the share of income accruing to each of the education-experience cells to calculate all group averages reported in this table. The percent wage changes refer to the product of the log wage change times 100. 